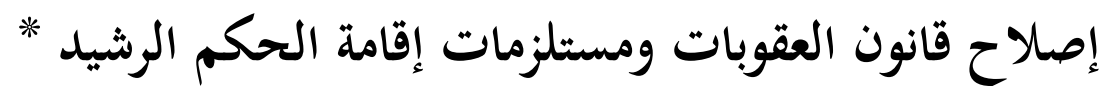

\title{
Reform of criminal Code and Requirements building of Good Governance
}
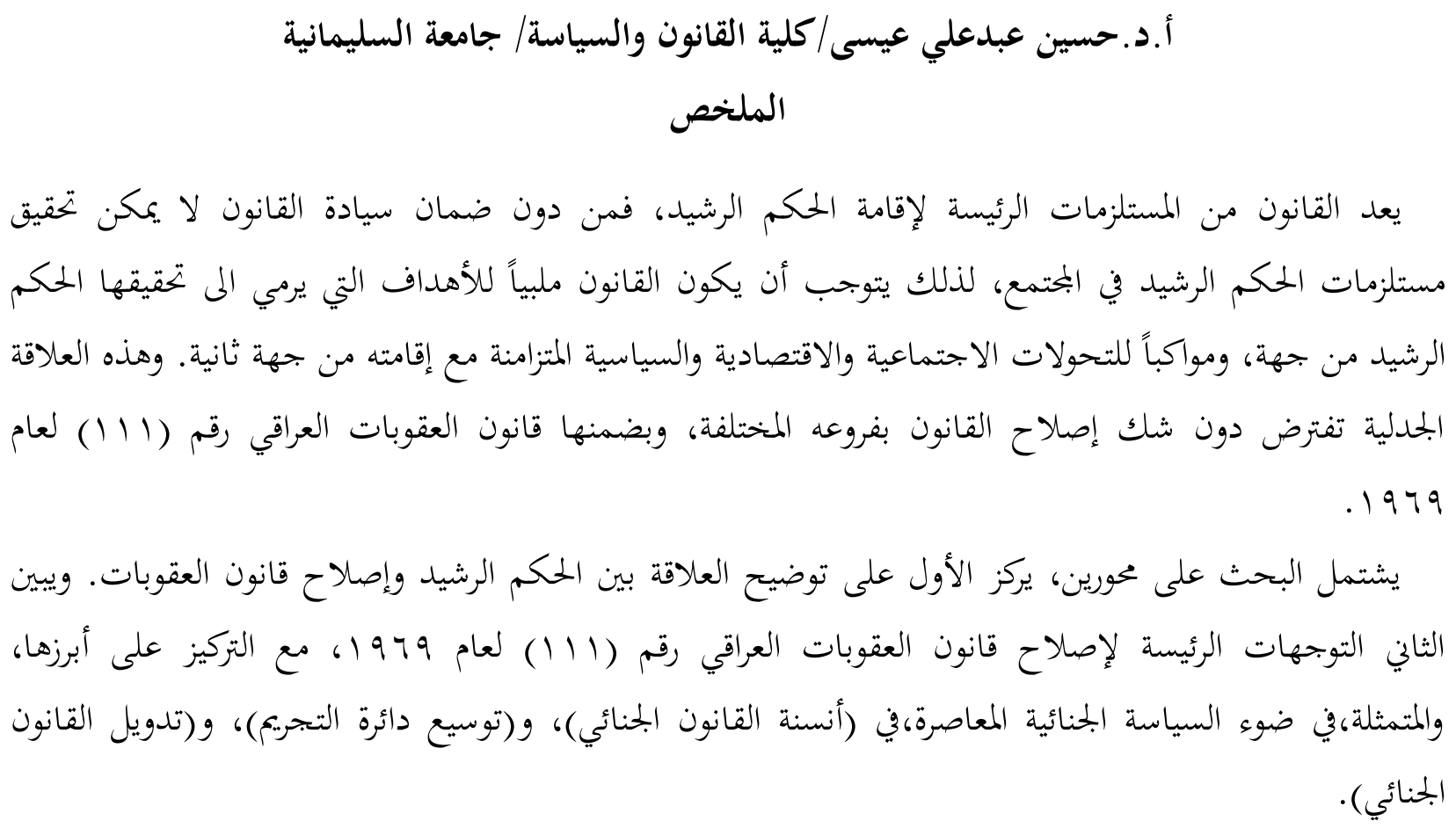

\section{Abstract}

The law is a key input for the establishment of good governance, it is no guarantee the rule of law cannot achieve good governance in the community requirements. So the law must be responsive to the objectives which aims to achieve good governance on the one hand, and the line with the social, economic and political transformations concurrent with his other hand. This dialectical relationship assumes without doubt the various branches of law reform, including the Iraqi Penal Code No. 111 of 1969.

The purpose statement that includes research on two aspects, the first focuses on clarifying dialectical relationship between good governance and reform of the Penal Code. The second shows the main directions of the reform of the Iraqi Penal Code No. 111 of 1969, with a focus on the most important, in the light of contemporary criminal policy. It is limited to the humanization of the criminal law), and (expand criminalization circle), and (internationalization of the criminal law). 
الحكم الرشيد هوالحكم الذي يعزز ويدعم ويصون رفاهية الإنسان، ويتسم بمبادئ: المشاركة، والشفافية،

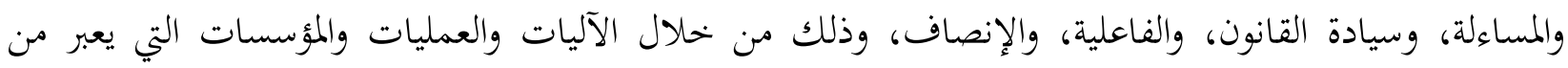
خلالها المواطنون والمحموعات عن مصالحهم، ويمارسون فيها حقوقهم الأساسية أوالدستورية.

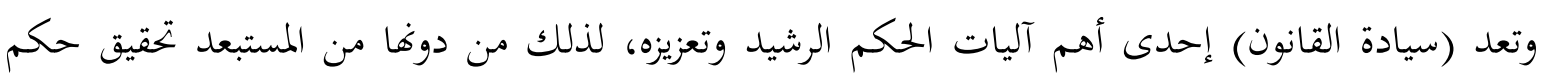
رشيد حقيقي، فالعلاقة بينهما هي علاقة وثيقة ومتبادلة، فتجسيد أحدهما في الواقع العملي مرتبط بوجود الآخر. ومن أجل تحقيق ذلك في حياة المجتمع بصورة ناجحة من المهم أن يكون القانون المعتمد تطبيقه في بحتمع

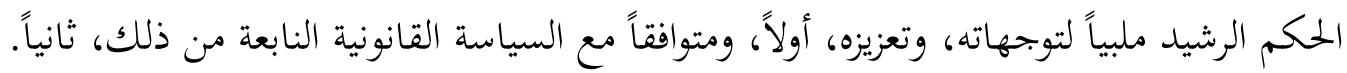
لقد صدر قانون العقوبات العراقي رقم (11) النافذ في عام 979 11، ومنذ ذلك الحين ولحد الآن طرأت عليه كثير من التعديلات التي جسدت السياسة الجنائية للدولة العراقية في مواجهة الإجرام خلال المرحلة المنصرمة، وكذلك

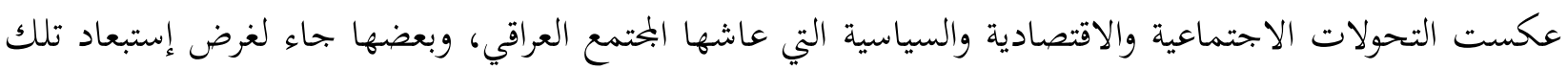

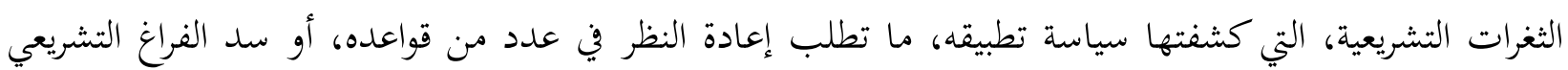

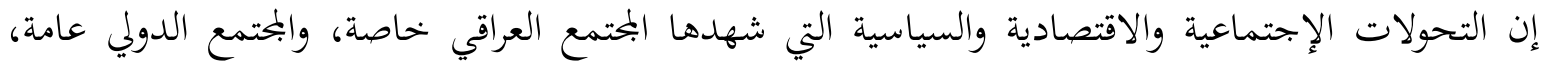
وكذلك التطورات الكبيرة والمتلاحقة التي شهدها السياسة الجنائية المعاصرة تفترض إجراء إصلاح جوهري على قانون

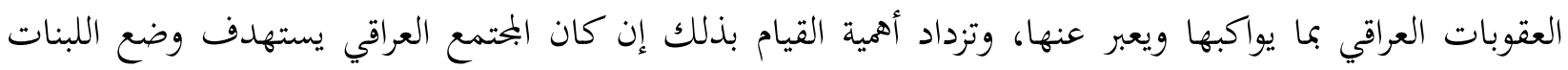
الأساسية لإقامة الحكم الرشيد، لاسيما وأن القانون يعد على رأسها.

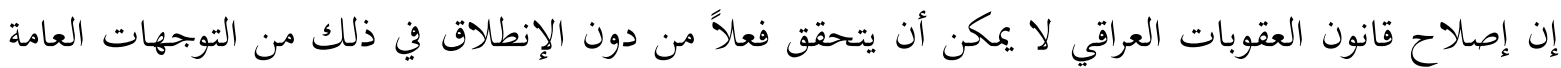
التي تحددها السياسة الجنائية بالنسبة لعملية الاصلاح المبتغاة، ذلك لأن السياسة الجنائية تعني السياسة التي توجه

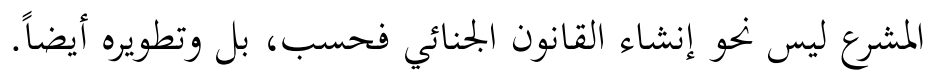
إن الباحث في نطاق هذا البحث لا يضع نصب عينيه النظر في ثغرات قانون العقوبات العراقي كلها، فقد سبق له ولغيره التطرق الى عدد كبير منها، فالهدف المطروح فيه يتمثل في سد تلك الثغرات التي يتضمنها هذا القانون

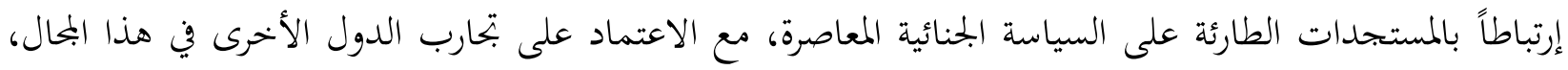
أي على أساس تحليل القوانين العقابية لعدد من الدول، البعض منها يعد من القوانين الحديثة، والبعض الآخر أجريت عليه تعديلات جوهرية، لكي يكون مواكباً لهذه المستجدات. 
وفي ضوء ما تقدم، سيتوزع هذا البحث الى مبحثين، يركز الأول على توضيح العلاقة بين الحكم الرشيد وإصلاح قانون العقوبات، في حين يخصص المبحث الثاني لإصلاح قانون العقوبات العراقي في ضوء السياسة الجنائية المعاصرة، وذلك على الوجه الآتي:

\section{المبحث الأول}

\section{العلاقة بين الحكم الرشيد وإصلاح قانون العقوبات}

تنبع العلاقة بين الحكم الرشيد وإصلاح القانون عامة، وإصلاح قانون العقوبات خاصة، من الصلة الوثيقة بين

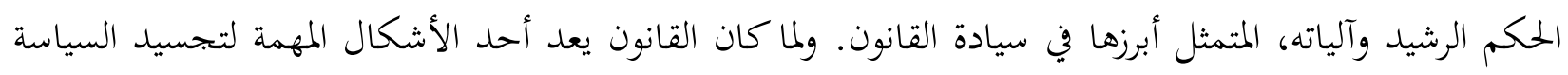

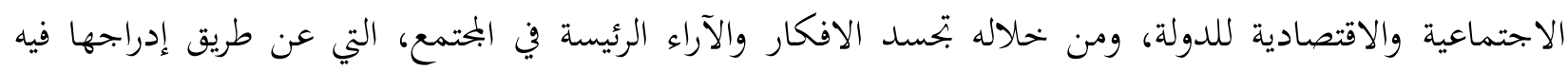

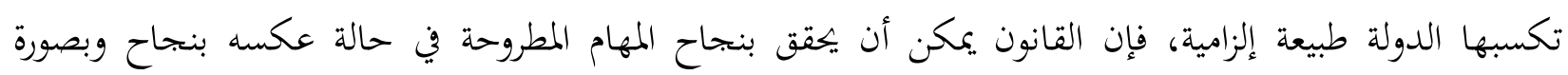
صحيحة الواقع الاجتماعي، وكذلك عند مراعاته لآفاق تطور المجتمع نهو إقامة الحكم الرشيد.

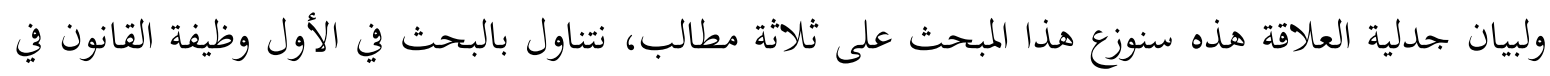
البحتمع، وفي الثاني دواعي إصلاح قانون العقوبات، وفي الثالث توجهات هذا الإصلاح، هلئ وعلى الوجهه الآتي:

\section{المطلب الأول}

\section{وظيفة القانون في المجتمع}

لابد للمجتمع من قواعد عامة تحد من حريات أفراده ورغباقم المطلقة، وتعمل على التوفيق بين مصالحهم

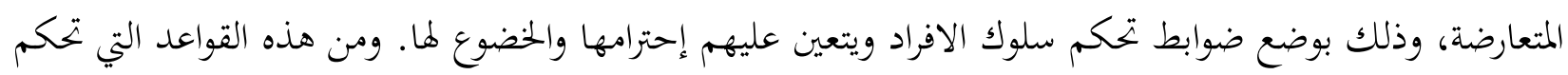

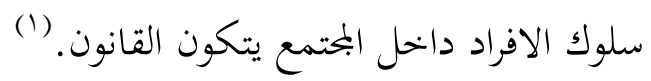
فوظيفة القانون تتمثل في العمل على التوفيق بين مصالح ورغبات أعضاء الجماعة المتعارضة بما يجفظ الأمن

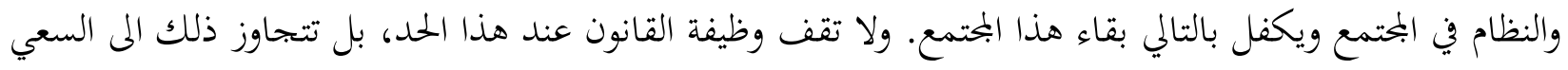

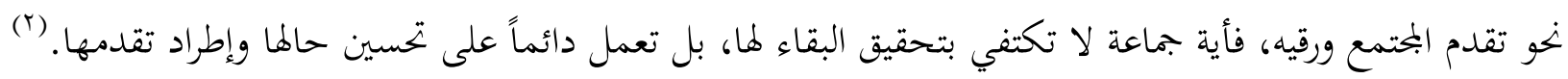

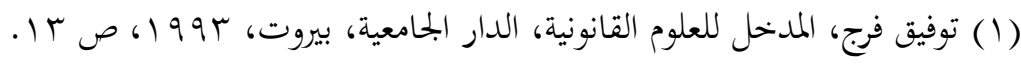

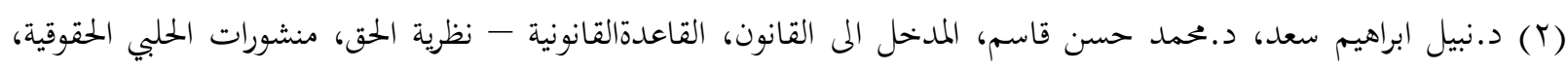

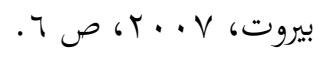


إصلاح قانون العقوبات ومستلزمات إقامة الحكم الرشيد من جانب المخاطبين بأحكامه تتوقف الى حد كبير على مدى تحقيقه للعدل، فالعدل كما قال أرسطو:"يجعلنا نحترم القوانين والمساواة"، (1) لذلك يتوجب على المشرع أن يستلهم العدل في سنه القوانين، إضافةالى المحافظة على كيان الجماعة والنظام فيها والعمل على إستقرار الأمن والمعاملات. (r)

إن التطلع الى العدالة يضع إحترام الفرد في الحياة الاجتماعية، هدفاً أساسياً وهائياً للقانون، الا إن تحديده للعدالة لا يتسنى الا بواسطة الهدف الذي يحدده المجتمع. ولما كانت الحياة في الجمتمع يجب أن تؤدي الى إزدهار الانسان، فهي يجب أن تؤدي له ما يسحقه، تبعاً لوسائله، مع مراعاة ما تتطلبه منه. (r)

وبهذا الخصوص أشار الفيلسوف هوبز الى إن المعيار الوحيد للعدل هو القانون ذاته بجيث إن أية قاعدة يضعها

القانون يجب، كأمر واقع، أن تكون عادلة في ذاتها. (ع) الا أن بحرد وجود قوانين عادلة دون سيادتا، يجعلها عديمة الجلدوى، وقد لا يقل ضررها عن ضرر القوانين غير العادلة. وسيادة القانون تتحقق بتطبيقها الفعلي، على النحو الصحيح، وبغير تمييز بين المشمولين بأحكامه. لذلك تنعدم سيادة القانون في الأحوال الآتية:

\section{ا -عند إهمال تطبيق القانون، فينعدم وجوده فعلاً.}

ب-عند التطبيق الخاطئ للقانون عمداً أو جهالً، مما يشوه الغرض الذي شرع من أجله، فينعدم وجوده

\section{حكماً.}

ب-عند عدم تطبيق القانون على بعض المشمولين بأحكامه، أو التساهل معهم عند تطبيقه عليهم، مما يعدم وجوده في الحالة الأولى، ويجرده من العدالة في الحالة الثانية، فيثير في الحالتين الشعور بالظلم والطغيان،

$$
\text { مما يدفع الى التمرد على أحكامه. (0) }
$$

وهناك من يكصر وظيفة القانون في حماية حريات الافراد ومصالحهم الخاصة، وحفظ كيان المحتمع وكفالة تقدمه. (1) ولتحقيق ذلك، ينبغي أن يقوم القانون بالتوفيق بين الحريات والمصالح المتعارضة توفيقاً يحفظ للمجتمع كيانه ويكفل

(1) نقلاً عن: سمير تناغو، النظرية العامة للقانون، منشأة المعرف، القاهرة، 910 1، ص سبا ا.

(Y) د. نبيل ابراهيم سعد، د. محمد حسن قاسم، المدخل الى القانون، مصدر سابق، ص • ل1 وما يليها.

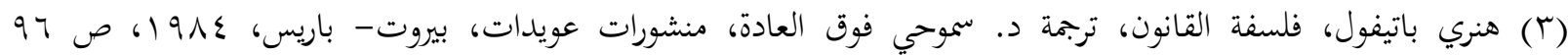
وما يليها، ص ع • 1 وما يليها.

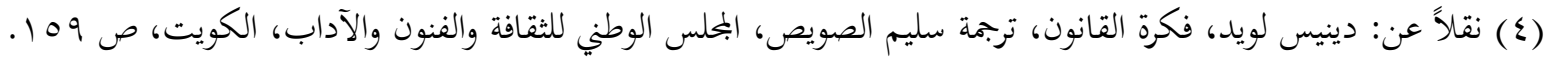

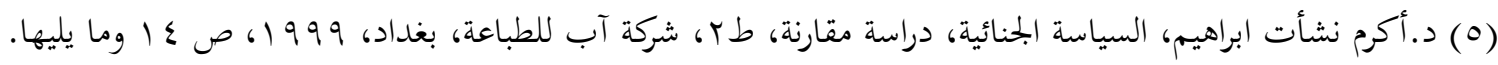


إرتقائه، وذلك على أساس من الحرية والمساواة، وتققيق المصلحة العامة، مع الاسترشاد بالعوامل المادية والمعنوية، التي

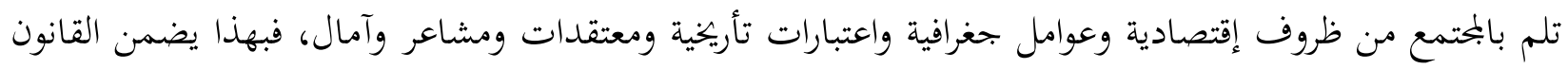
التنظيم العادل للمجتمع الذي قوامه صيانة الفرد وتعقيق الخير العام.

ويرى البعض (r) إن الحاجة الناجمة عن المصلحة الاجتماعية الرئيسة المتمثلة في تحقيق الاستقرار العام، وهذه

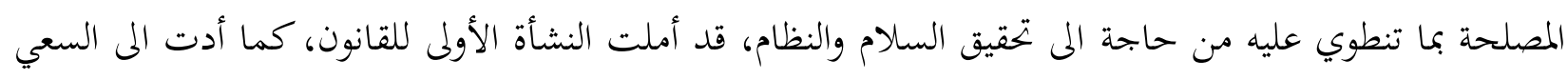

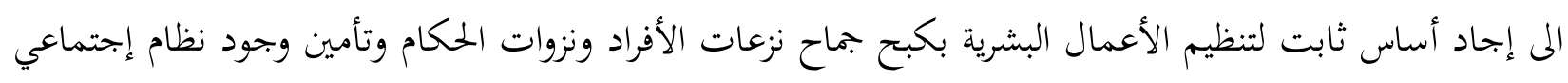

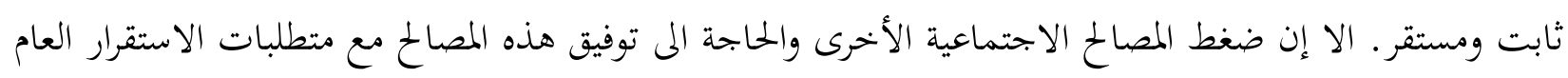
وإيجاد تسويات مستمرة نابتحة عن التغييرات المستمرة في المجتمع، قد إستوجبت إصلاح المفاهية القانونية بإستمرار

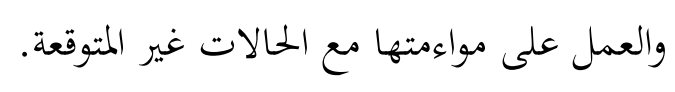
لقد تعددت المذاهب المتعلقة بتحديد طبيعة القانون وماهيته وغاياته، وهناك من يشير الى إثنتي عشر مذهب،

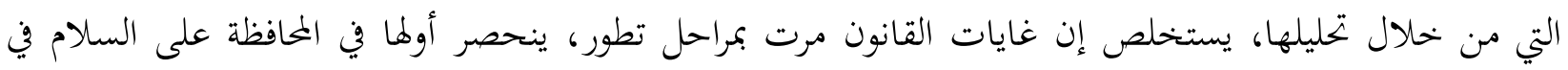
بجتمع معين، وذلك في جيمع الظروف ومهما كان الثمن، فغاية القانون هي الوفاء بالحاجة الاجتماعية للاستقرار

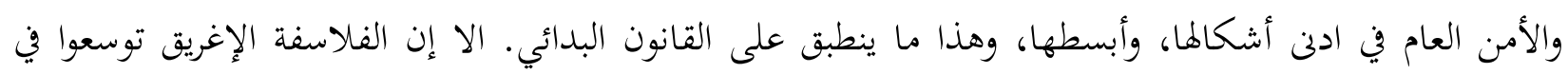

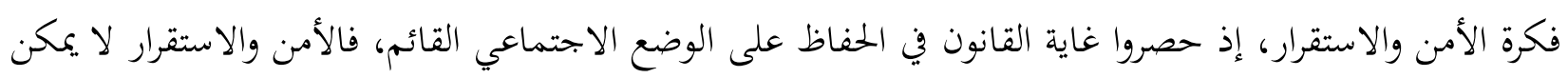

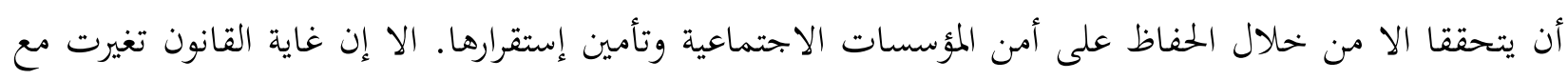

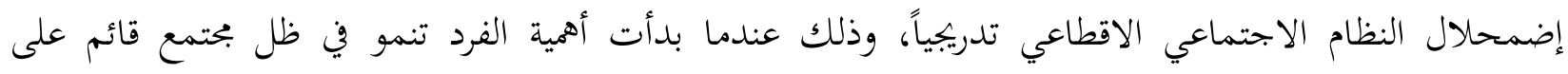

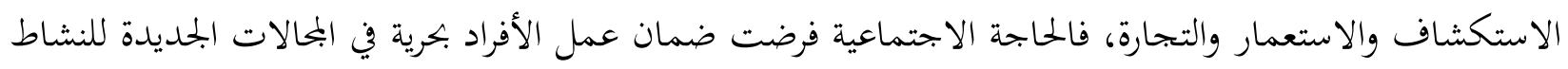

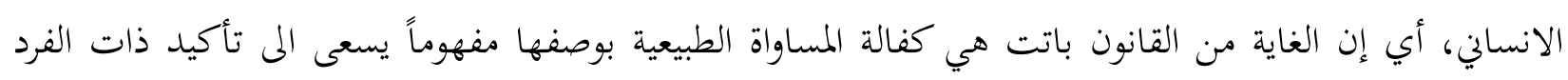

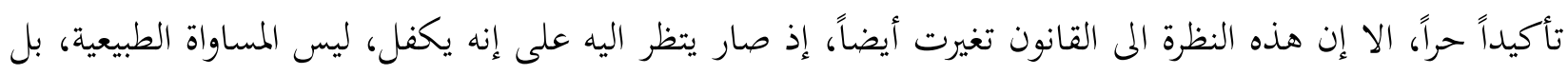

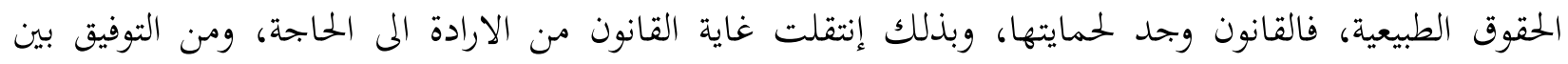

(1) عبدالباقي البكري، زهير البشير، المدخل لدراسةالقانون، بيت الحكمة للنشر والترجمة والتوزيع، بغداد، ب.ت.تأريخ النشر، ص ا17 17 وما يليها.

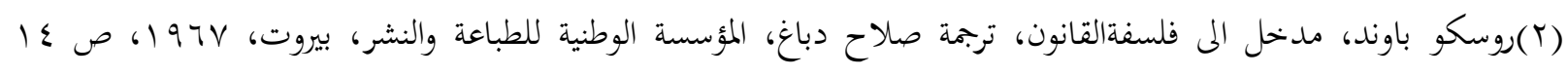
و 


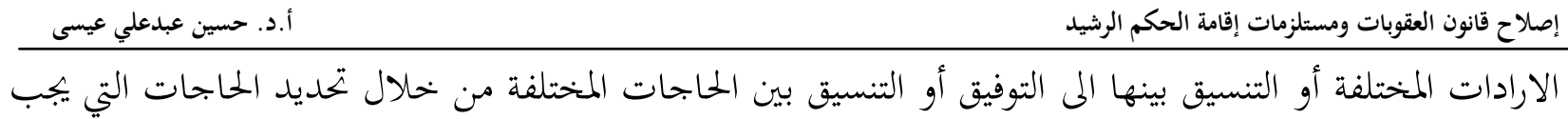

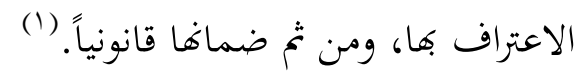

وفي ضوء ما تقدم، فإن وظيفة القانون، فضلاً عن أهميتها بالنسبة لأي بحتمع، فهي تعد كبيرة في المجتمع الذي

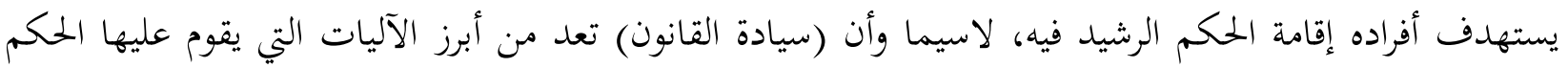

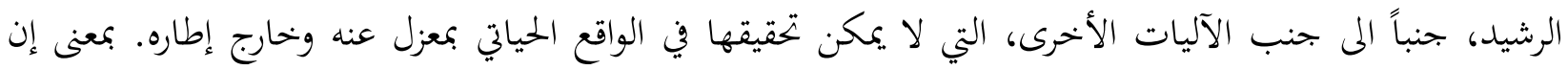

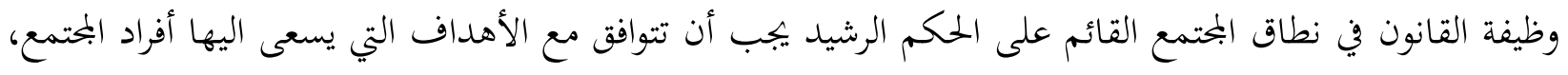
والمتمثلة في بناء مرتكزاته، وعلى العكس من هذا فإن قانوناً لا يجسد هذه الأهداف إنما يعني تعارضه مع توجهات الحكم الرشيد وأهداف القائمين على إقامته في المجتمع. المطلب الثاني

\section{دواعي إصلاح قانون العقوبات}

إن على القانون أن يساير ظروف الحياة الاجتماعية دائمةالحركة، حتى يمكنه تحقيق وظيفته كأداة للتقدم والرقي

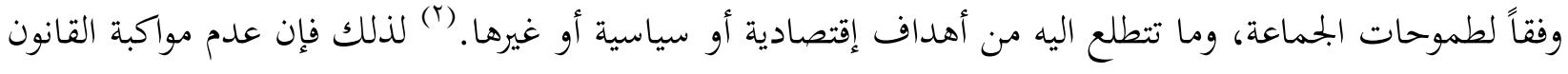

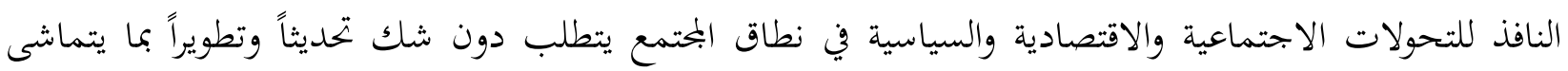
معها، فتطوير القانون يعني قيام الدولة، وبالوسائل القانونية، برفع فاعلية القواعد القانونية من خلال تعديلها أو إلغائها أو إستحداث قواعد قانونية جديدة.

الا إن تطوير القانون قد يتعارض مع ثباته، فبقاء القانون دون تغييرات جوهرية لمدة طويلة من الزمن هو، بلا شك، دليل على دقة صياغته وصحة الأفكار والمبادئ التي يقوم عليها، وفي ضوء هذا الثبات تتعزز سمعة القانون

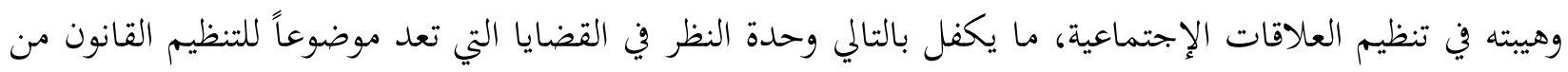
خلاله. كما إن ثبات القانون دليل على ثبات العلاقات الإجتماعية القائمة دون تغييرات جوهرية تستدعي تغيير القانون أو إصلاحه. () وفي الوقت عينه، إن القانون نفسه هو عامل لإستقرار الحياة في المجتمع، فهو يعمل على إرساء

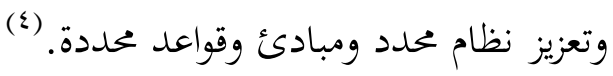

(1) روسكو باوند، مدخل الى فلسفة القانون، المصدر السابق، ص 9r-oV.

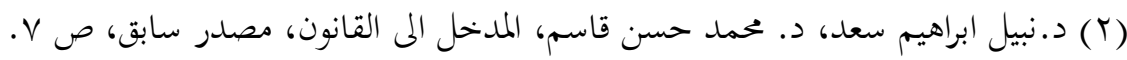

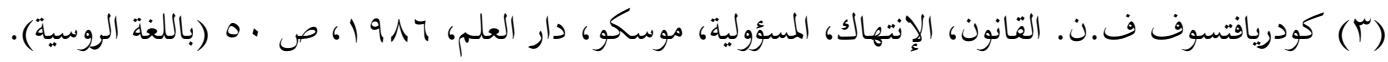

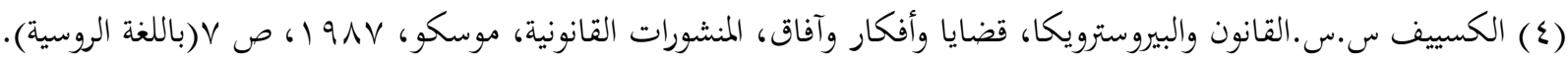
14 
إن القانون يمكن أن يحقق وظيفته التي حددها المشرع عندما يكون بحسداً حقاً للواقع الإجتماعي المعاش من

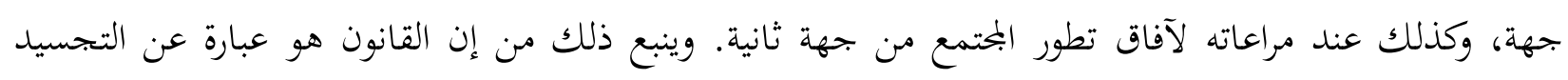

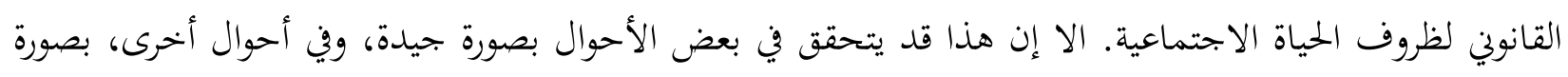

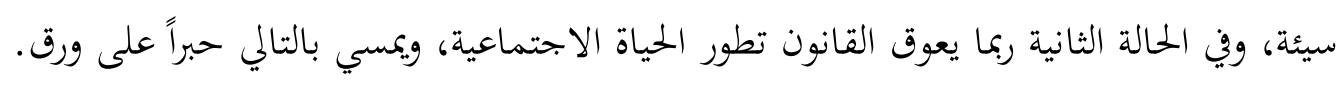

لذلك فإن تأريخ التجريم والعقاب في تغير دائم وفقاً لما تقتضيه الضرورات الاجتماعية، بل إن قيمة القواعد

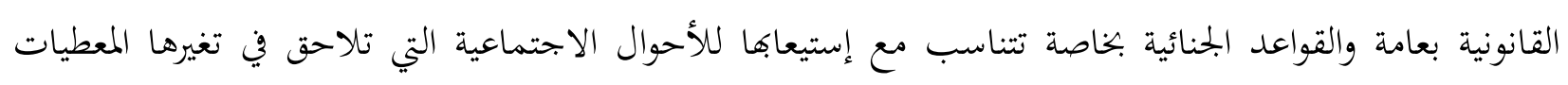
الاقتصادية والسياسية والثقافية والدينية. (')

إن طرح مطلب إصلاح القانون، على وجه العموم، يكون مرتبطاً بإحتوائه على ثغرات جوهرية، التي يمكن أن

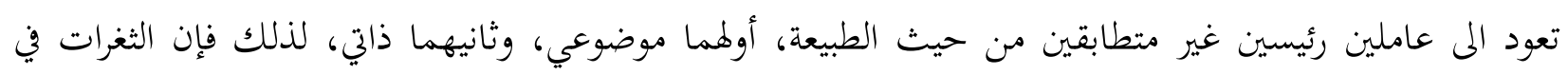

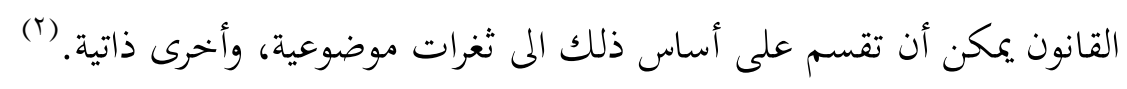
وتكون الثغرات موضوعية عندما ترتبط بالتغييرات المستمرة الطارئة على العلاقات الاجتماعية التي تعد موضوعاً

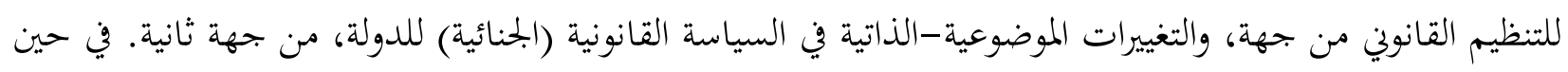

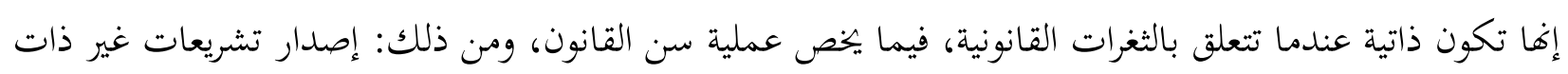

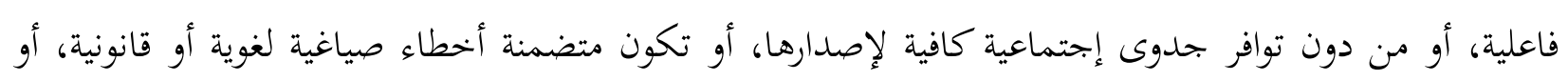

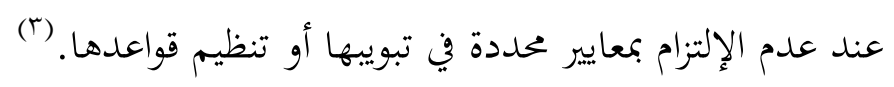

وإرتباطاً بزمان ظهور الثغرات يمكن توزيعها المى ثغرات إبتدائية، وتغرات لاحقة، وتظهر الأولى لحظة إصدار

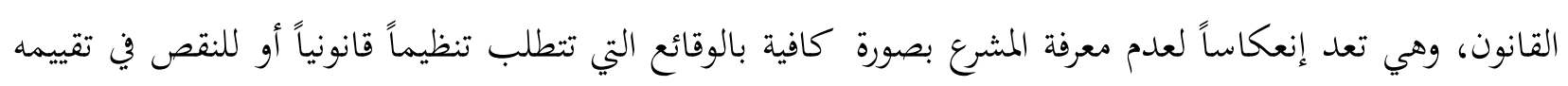

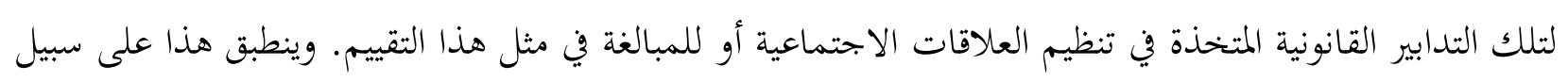

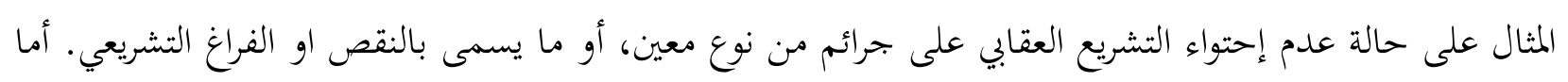

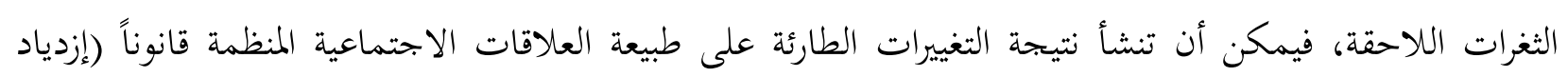

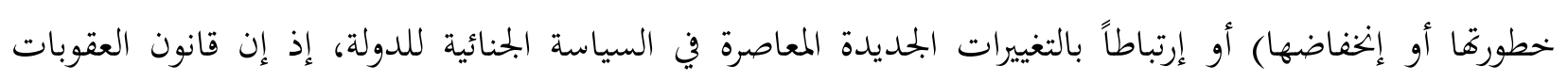

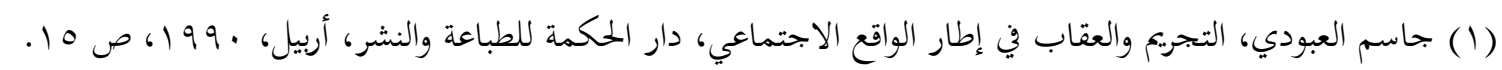

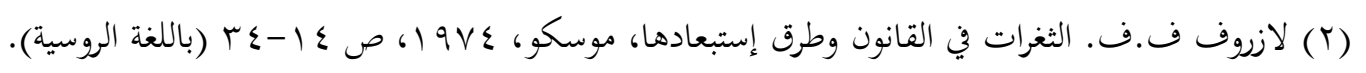

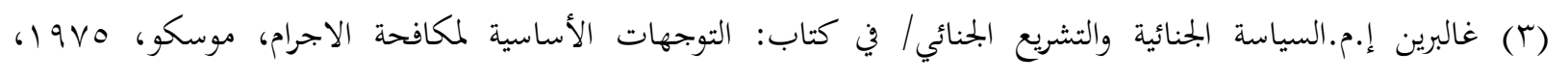

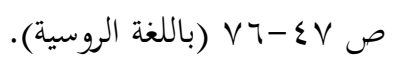




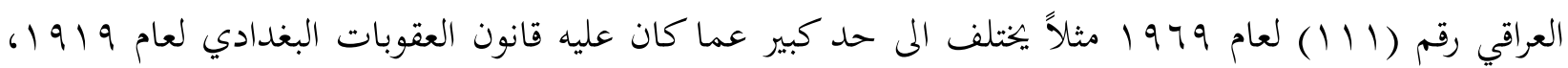

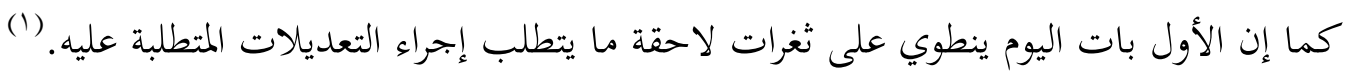

إن الثغرات قد ترتبط في بعض الأحوال بحصول أخطاء في تحرير إصدار القانون أو عند طبع القانون في الجريدة،

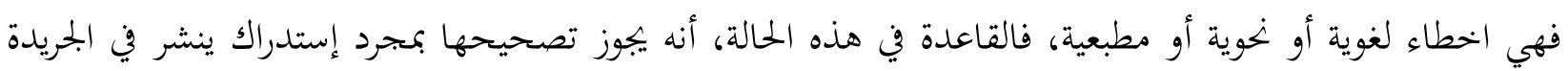

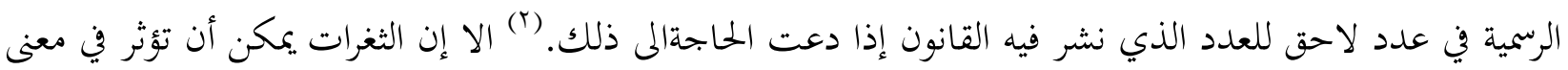
القانون أو مضمون أحكامه (جوهره)، ففي هذه الأحوال يتوجب على السلطة التشريعية إصدار قانون جديد تصحح به الأخطاء التي تضمنها القانون الأول. (")

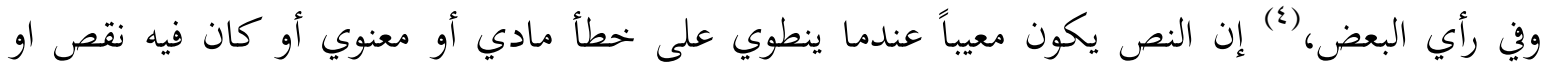

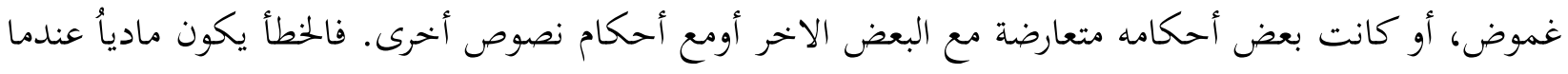
يكون هناك خطأ في تعريف لمفهوم جريمة ما، وفي بعض الأحوال يكون مرتبطاً بخطأ في ترجمة مصطلح، أما الخطأ أحسأ

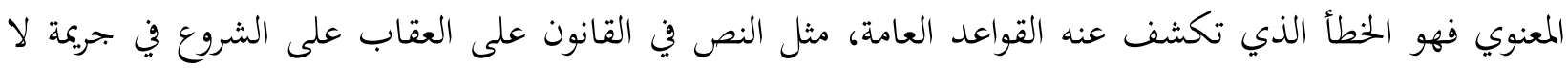
يتحقق فيها ذلك لكوها من جرائم الفعل البحرد مثلاً.

ويتمثل النقص في إغفال لفظ لا يستقيم الحكم بدونه، مثل عدم الاشارة الى أحد عناصر الجريمة على الرغم

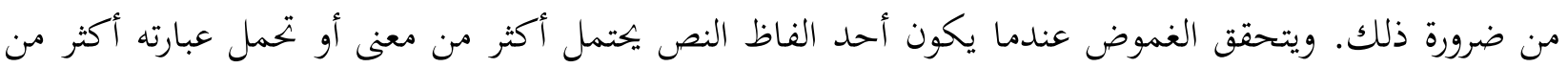

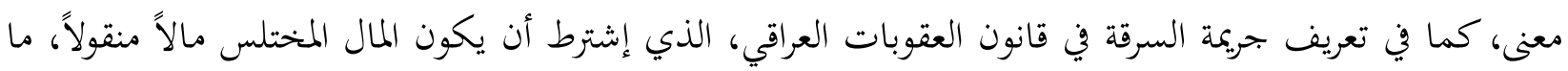

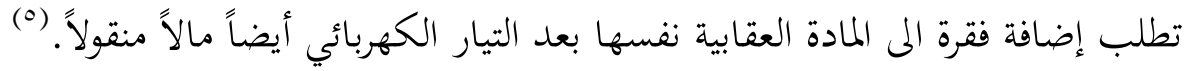

(1)لتنفاصيل حول ثغرات قانون العقوبات العراقي أنظر بحوثنا:، الاتحاهات الرئيسة لتطوير التشريع العقابي العراقي، القانون والسياسة، كلية القانون والسياسة، جامعة صلاح الدين، العدد r، كانون الأول ه ـ. . ب، الثغرات في قانون العقوبات، أسبابها ووسائل

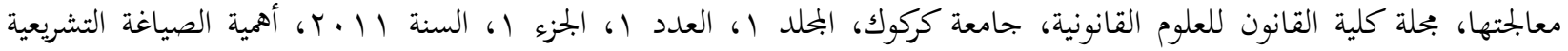
لقانون العقوبات في تكييف الوقائع الاجرامية، بحلة جامعة تكريت للعلوم القانونية والسياسية، جامعة تكريت، المجلد ع، العدد با ال، آذار r ا. r. (Y) د. نبيل ابراهيم سعد، د. محمد حسن قاسم، المدخل المى القانون، مصدر سابق، ص سج 1 .

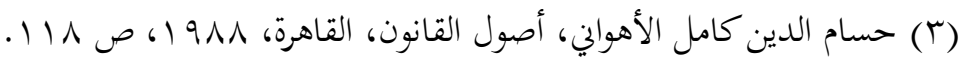

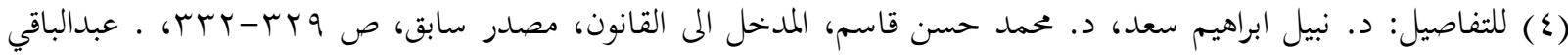

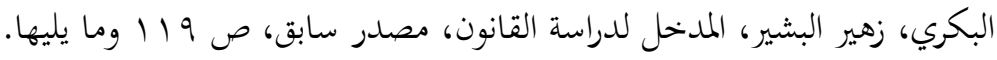

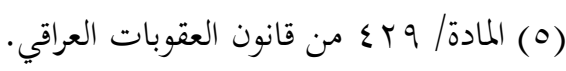


أما عن التعارض، فيمكن أن يكون بين تشريعات متفاوتة في الدرجة، أو بين نصوص تشريع واحد أو نصوص تشريعات متساوية في القوة أو صادرة في وقت واحد.

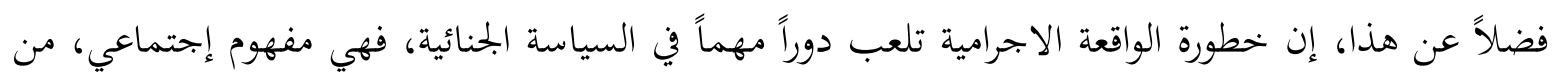

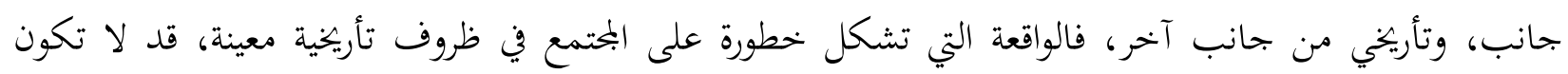

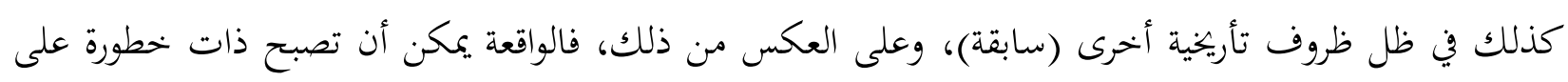

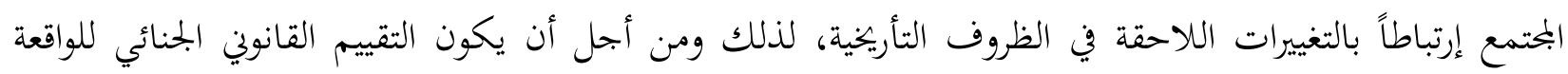

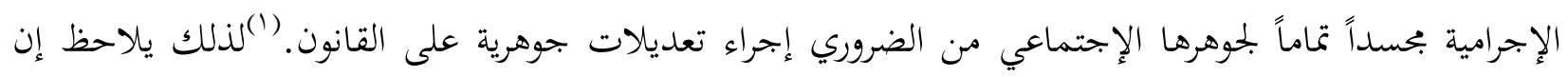

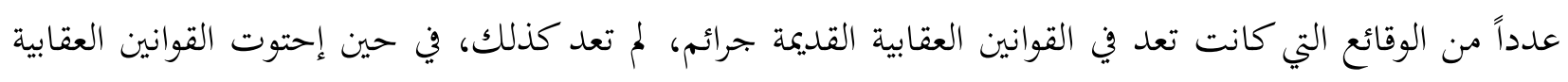
المعاصرة على جرائم لم تعرفها القوانين العقابية القديمة.

\section{المطلب الثالث}

\section{توجهات إصلاح قانون العقوبات}

كيف يمكن أن يجري الإصلاح المنشود لقانون العقوبات؟ إن هذا يرتبط، في المقام الأول، بفاعلية القانون

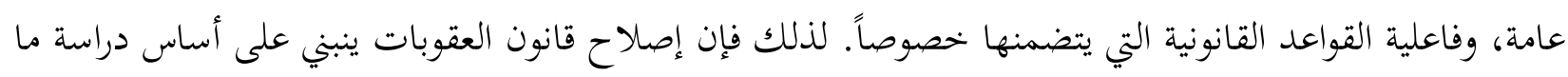

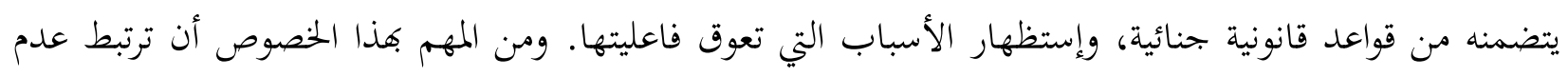

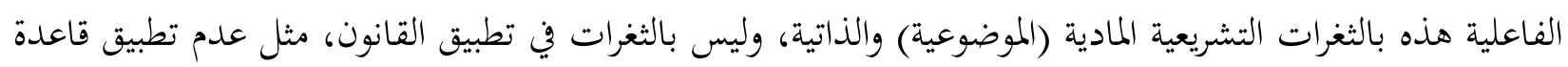

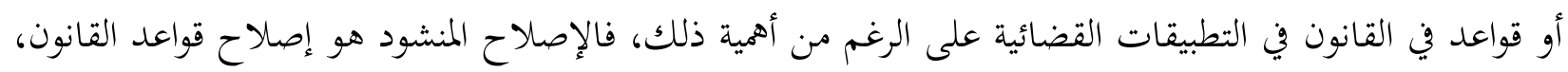

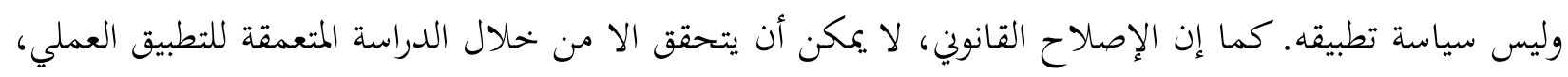

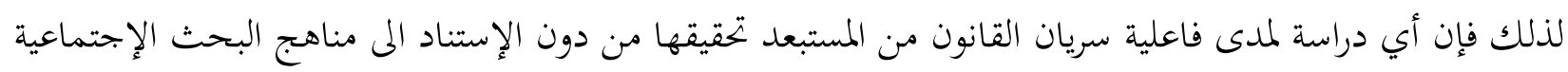
ذات الصلة. (ז)

فضلاً عن هذا، إن التوصيات المتعلقة بإصلاح قانون العقوبات يتوجب أن تتوافق مع مبادئ السياسة الجنائية

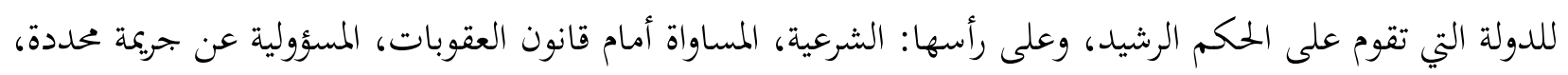

$$
\text { (1) كودريافتسوف ف.ن. الأسس النظرية لتكسيف الجرائم، موسكو، بالب 19، ص 00 (باللغة الروسية). }
$$

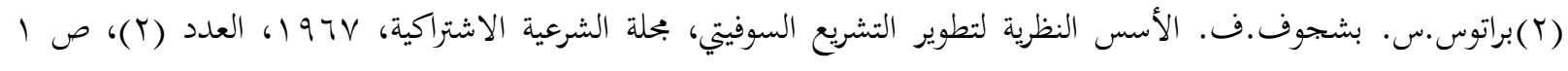
(باللغة الروسية). 


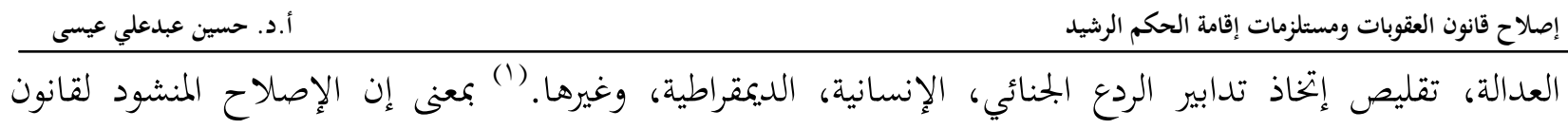
العقوبات يكون إنعكاساً لسياسة الدولة بالنسبة لمواجهة الاجرام في المجتمع، وهذا يفترض، في الوقت عينه، التطوير المتزامن مع التحولات الاجتماعية للمبادئ السابقة الذكر، وبحسيدها في قواعد التشريعات العقابية المعتمدة في بحتمع

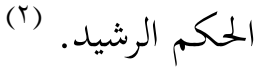

إن الاصلاح المنشود لقانون العقوبات إنما يتعلق بمجتمع يسعى الم إقامة الحكم الرشيد، أو يستهدف تعزيز ركائزه، لذلك بات من مقتضيات هذا الاصلاح أن ينبع من خطة التنمية الاقتصادية- الاجتماعية للدولة، وبما ينسجم مع خصائص البلد المعني، كما إن سياسة التجريم والعقاب يتوجب أن تمدف الى تحقيق مقتضيات مصالح كل

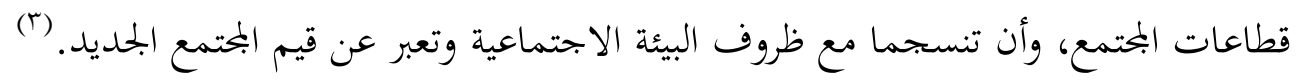
ومن الملاحظ إن السياسة الجنائية على توالي مراحلها في المجتمعات البشرية قد تفاعلت مع التطورات التي لحقت عموم الأوضاع الاجتماعية في هذه البحتمعات بحيث أصبح من الثابت إن السياسة العامة قد تركت بصماها العميقة على السياسة الجنائية ودفعت بها أشواطاً بعيدة في ذات إبحاهها الذي يمثل الجانب المحرك للآيديولوجية

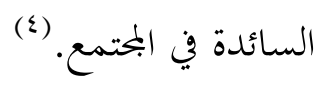

كما إن للوعي القانوني أبلغ الأثر في رفع فاعلية القواعد القانونية، فالقاعدة القانونية البحسدة لتصورات أفراد الجمتمع والتي تتوافق مع أفكارهم، تكون أكثر فاعلية مقارنة بتلك القواعد القانونية التي لا تتوافق مع هذه التصورات والأفكار. بمعنى إن نفاذ القاعدة القانونية يكون فاعلاً أكثر عندما يتوافق مع الجوانب الاجتماعية - النفسية للوعي القانوني. (0) وهذا يقود الى القول، بإن إصلاح القانون في نطاق الحكم الرشيد يتوجب أن يتوافق مع توجهات الوعي القانوني الاجتماعي الذي يقوم عليه.

إن هناك علاقة وثيقة بين إصلاح القانون ومستوى الوعي القانوني وطبيعة سلوك المواطنين، اللذين يجري تقييمهما على مختلف المستويات: المحتمع عموماً، الجماعات الاجتماعية، الفرد، وبهذا يتوزع الوعي القانوبي الى وعي قانولي إجتماعي، وجماعاتي، وفردي. لذلك لا يمكن القول بتحقق الاصلاح المنشود بمراعاة الوعي القانوني لذذه

(1)بحثنا: المبادئ الدستورية للسياسة الجنائية، بحلة جامعة السليمانية (كوفارى زانكوى سليمانى به شى B)، العدد VI نيسان

ف) (Yحول أهمية المبادئ المذكورة في إصلاح قانون العقوبات أنظر: قانون العقوبات، تحربة الأنموذج النظري، تحت إشراف

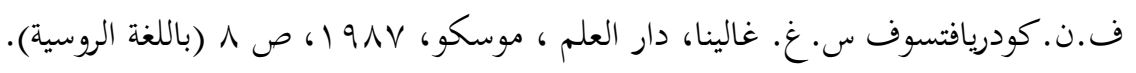
(r) جاسم العبودي، التجريم والعقاب في إطار الواقع الاجتماعي، مصدر سابق، ص V V وما يليها.

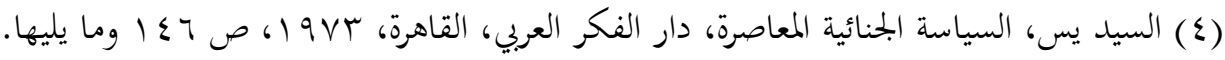

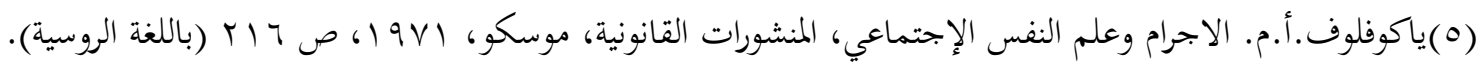


الجماعة أو تلك لا غير. كما إن مستويات الوعي القانوين في نطاق الحكم الرشيد وثيقة الصلة بعملية إصلاح القانون، فالثغرات في القانون من الصعب أن تخظى بالقبول في ظل الوعي القانوني الاجتماعي العالي، والأمر نفسه إنه

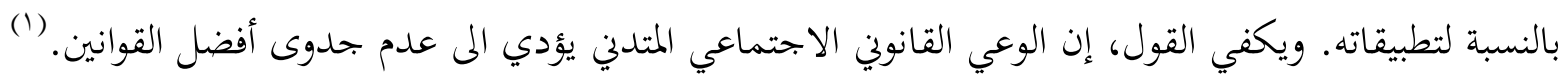
ولكن، ما هي التوجهات التي يتوجب أن ينطلق منها الاصلاح القانوني؟ إن أبرز هذه التوجهات يمكن أن تنحصر فيما يأتي: وني أولاً: السعي نحو تضمين قانون العقوبات حلول تلك المسائل المتعلقة بالمسؤولية الجنائية، تلك التي تجد مكاها، ليس في القانون، بل في نظرية القانون الجنائي، أو في التوجيهات الصادرة من المحاكم الأعلى درجة. ثانياً: من المهم تحديد الفاصل، وبدقة، بين السلوك الذي يعد جريمة، والسلوك الذي لا يعد كذلك، فالبت في

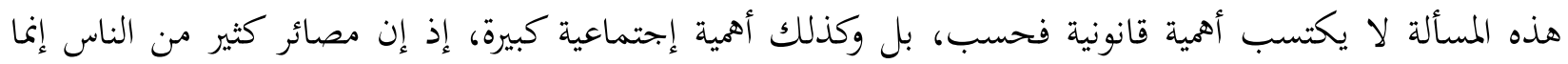
ترتبط بذلك. وهذا ما يحدد الوجه الأخلاقي للمجتمع، فعدم الوضوح والتداخل في الحدود بين السلوك الاجرامي وغير الاجرامي يؤثر في عملية تطبيق القانون، وكذلك في الوعي القانوني الاجتماعي، وينتهك (الشعور بالعدالة

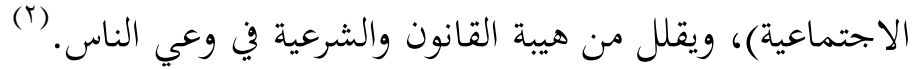

ثالثاً: ضمان ثبات عملية تطبيق القانون، لاسيما في حالة إحتوائه على قواعد تتضمن أركان جرائم يشوبها

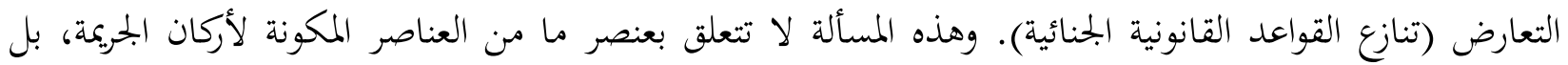

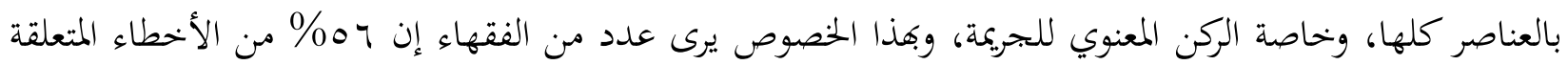

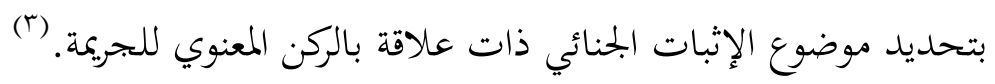
رابعاً: التبيت القانوين لمبدأ الشرعية في القواعد القانونية الجنائية، فهذا المبدأ يفترض منح حقوق متماثلة والإلزام بإلتزامات متماثلة بالنسبة للمواطنين كافة. أي إن الشرعية تفترض كذلك مساواة المواطنين أمام قانون العقوبات، كما

(1) كودريافتسوف ف.ن.شروط فاعلية القواعد القانونية/ في كتاب: فاعلية القواعد القانوينة، المنشورات القانونية، موسكو،

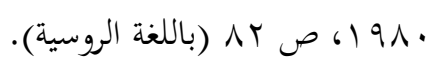

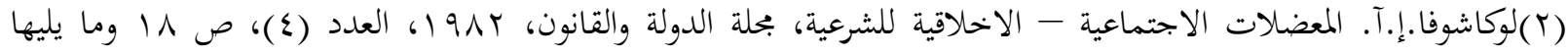
(باللغة الروسية).

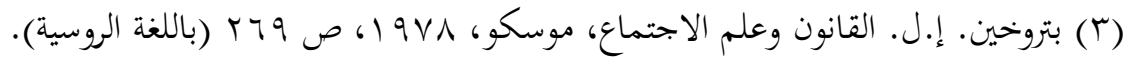


إنلاح قانون العقوبات ومستلزمات إقامة الحكم الرشيد

القانون والدولة والعدالة الاجتماعية وديمومة النظام القانوني وغيرها. (1)

فضلاً عما تقدم، إن إصلاح قانون العقوبات، الذي له مكانته الخاصة في نطاق النظام القانوني للدول، يتوجب أن يعبر عن سياسة الدولة في مكافحة الاجرام، وبما يرسخ مبدأ حتمية العقاب، وضمان إحتوائه على تلك التدابير العقابية المعبرة عن وظائف العقوبة الجزائية المتمثلة في (الجزاء والإصلاح والردع).

إن عملية الإصلاح في ظل الحكم الرشيد لا يمكن أن تتحقق، بطبيعة الحال، الا من خلال وضع سياسة جنائية (وطنية) تواكب التحولات الإجتماعية والاقتصادية والسياسية المتعلقة بالحكم الرشيد على وجه التحديد، وكذلك العمل على تجسيدها في التشريعات العقابية الصادرة. كما إن هذه العملية لا يمكن أن تحقق الغاية منها الا إن جاءت معبرة عن توجهات السياسة الجنائية المعاصرة، وطنياً ودولياً، تلك التوجهات التي بحد ضمانة لتجسيدها من خلال إصدار القوانين العقابية الجحيدة أو إجراء التعديلات الجوهرية على القوانين العقابية النافذة.

لقد دلت بحربة تطبيق قانون العقوبات العراقي منذ صدوره في عام 979 ا وحتى اليوم على إحتوائه من جهة على كثير من الثغرات، الأمر الذي يستدعي دراسة قواعده من طرف متخصصين في القانون الجنائي، والعمل على إستظهارها، ومعالجتها. كما إن التطورات المتسارعة على صعيد السياسة الجنائية المعاصرة، كشفت، من جهة ثانية، عن ثغرات عديدة أخرى في هذا القانون، ما يقتضي الأخذ الحتمي بالمستجدات الطارئة فيها، وعلى العكس من ذلك سوف يكون هذا القانون متخلفاً عن مواكبتها، ما سوف يعوق بناء مرتكزات الحكم الرشيد. لذلك، ومن أجل أن يكون قانون العقوبات العراقي بحسداً فعلاً لمتطلبات الحكم الرشيد، وعاملاً في تعزيز آلياته، ولاسيما (سيادة القانون)، من المتوجب أن تكون قواعده بحسدة لتوجهات السياسة الجنائية المعاصرة. المبحث الثاني

\section{إصلاح قانون العقوبات العراقيفي ضوء السياسة الجنائية المعاصرة}

السياسة الجنائية المعاصرة، هي حصيلة لتطور السياسة الجنائية ذاها، لذلك فهي تمثل المنجزات التي حققتها

على مدى قرون، سواءً أكان هذا على صعيد نظرية القانون الجنائي وفلسفته أم على صعيد سن القوانين العقابية الوطنية والمقارنة، وبتربة تطبيقاتا، ولإلقاء الضوء على أبرز التوجهات المعاصرة والتي يمكن إعتمادها في إصلاح قانون العقوبات العراقي سنتوقف، على وجه الخصوص، عند (أنسنة القانون الجنائي)، و (توسيع دائرةالتجريم)، و (تدويل القانون الجنائي)، وذلك في المطالب الثلاثة الآتية:

(1) كودريافتسوف ف.ن. القانون، الإنتهاك، المسؤولية، مصدر سابق، ص rه. 


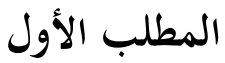

\section{أنسنة القانون الجنائي}

تعد (أنسنة القانون الجنائي)، التي تمثل توجهه الإنساني، توجهاً مهماً في تطور القانون الجنائي، وتعود بداياته

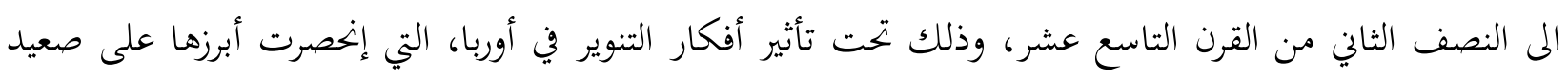

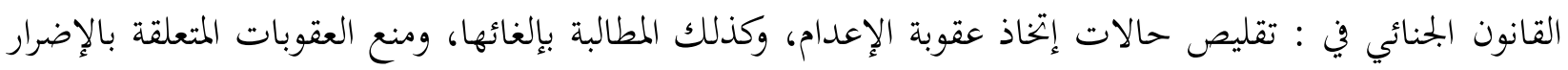
بأعضاء جسم الانسان، وكذلك العقوبات الصارمة، والإعفاء من المسؤولية الجنائية بالنسبة لصغار السن والاشتخاص المصابين بعيوب عقلية، ومن ذلك جرت، على سبيل المثال، في النمسا وروسيا وتوسكانيا في القرن الثامن عشر أولى

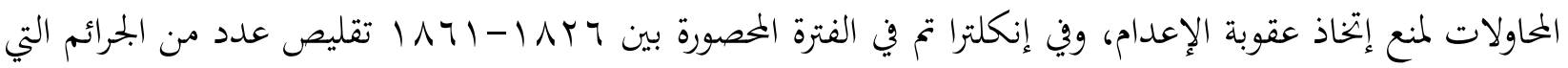

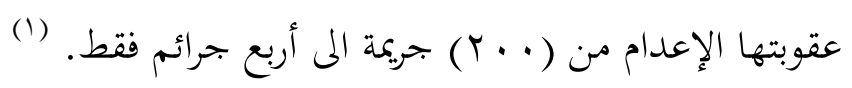

وفي النصف الأول من القرن العشرين طرأت تطورات إجتماعية وسياسية وإقتصادية كان لها اثرها في نشر أفكار

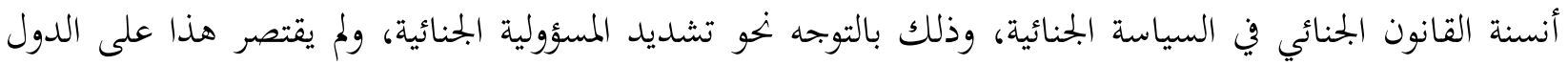

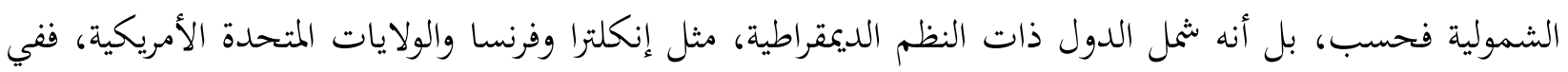

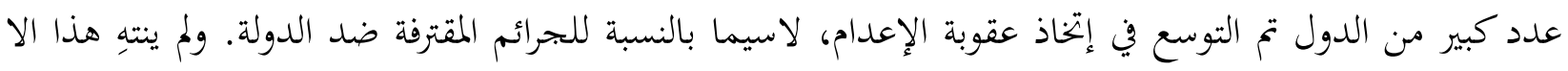

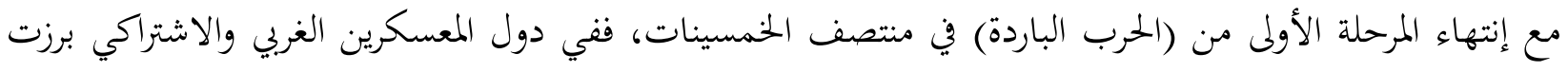
من جديد تلك المساعي التي تدعو الى أنسنة القانون الجنائي.

وفي ضوء هذا التوجه في السياسة الجنائية المعاصرة يلاحظ إن كثيراً من التشريعات العقابية عمل على تجسيده بقواعد تضمنته، ما يستدعي الأخذ به أيضاً عند طرح مسألة إصلاح قانون العقوبات العراقي رقم (111) لسنة 979 1979، مع مراعاة مظاهره الرئيسة، التي تتمثل فيما يأتي:

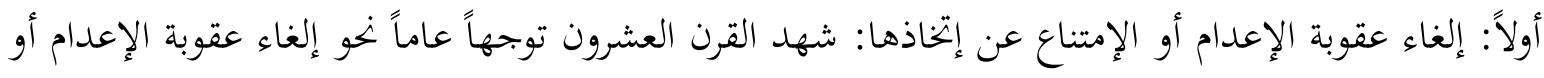

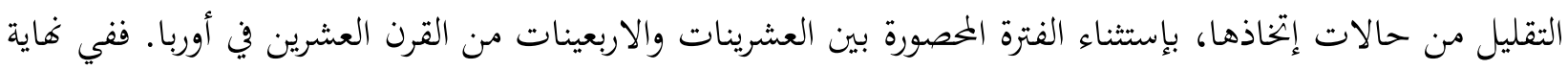

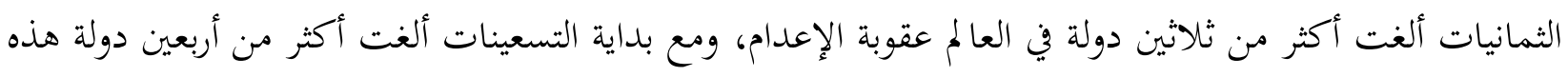

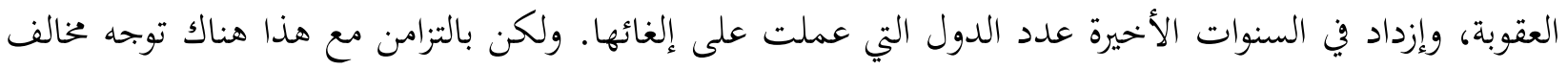

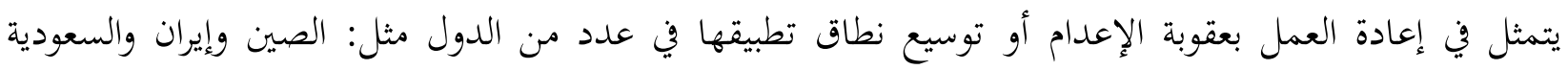

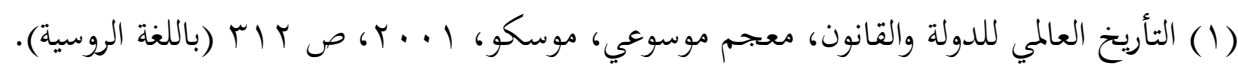


إصلاح قانون العقوبات ومستلزمات إقامة الحكم الرشيد

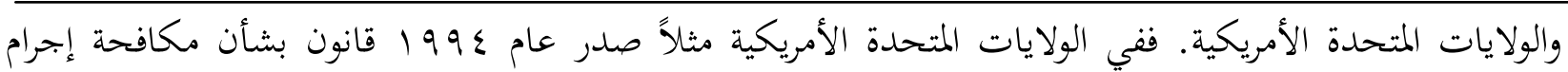

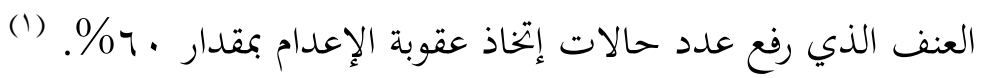

ثانياً: الغاء العقوبات البدنية: يعد إلغاء هذه العقوبات توجهاً عاماً في القانون الجنائي يعود الى حوالى مائتي سنة، إذ إنه برز في أوربا في القرن الثامن عشر تحت تأثير أفكار التنوير، وقد شهدت فرنسا لأول مرة إلغاء عدد من

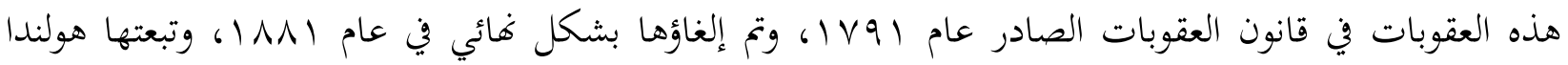

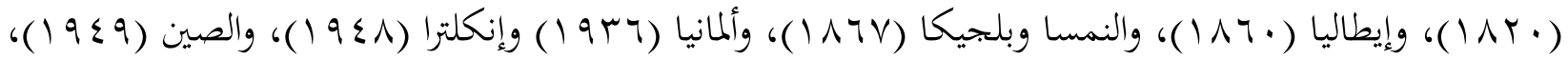

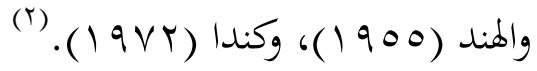

ولم تفقد هذه المسألة أهميتها في الوقت الراهن، إذ لاتزال القوانين العقابية في أكثر من عشرين دولة في العالم تنص عليها، لاسيما في عدد من دول أفريقيا، وكذلك في الدول الإسلامية. ويلاحظ التوسع في إتخاذ العقوبات البدنية على وجه الخصوص في الثمانينات، وذلك بعد سنوات طويلة لم تتخذ فيها، إذ أدرجت في التشريعات العقابية في ليبيا، وموريتانيا، وإيران، والسودان، وباكستان، واليمن، في حين إتخذ تطبيقها مديات واسعة في الامارات والمملكة العربيةالسعودية.

ثالثاً: عدم إتخاذ عقوبة الأشغال الشاقة: في بداية القرن العشرين كانت الأشغال الشاقة في أغلب الدول تقريباً تعد عقوبة تقليدية في القانون الجنائي، ولكن بعد الحرب العالمية الثانية تغيرت النظرة اليها، وأخذت تعد عقوبة صارمة،

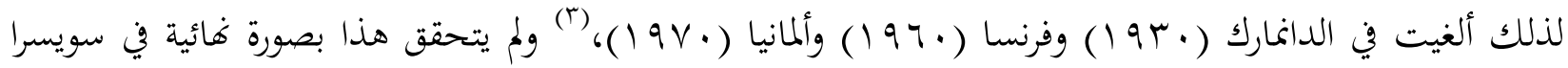

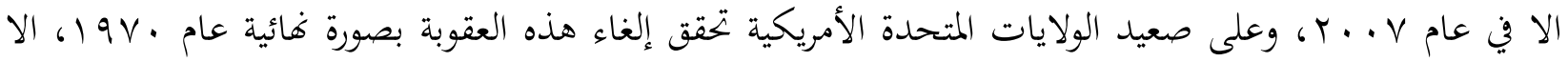
إذها أعيدت في ولاية الاباما، والغيت في عام V9919 أتحت ضغط الرأي العام.

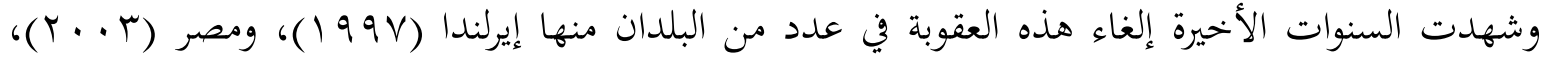

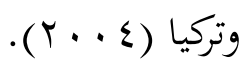

رابعاً: إلغاء عقوبة المصادرة العامة للأموال: يعود إلغاء هذه العقوبة من التشريعات العقابية الى مرحلة الثورة البرجوازية في فرنسا، إذ ألغيت في عام • V9 1، وذلك بحسيداً لحصانة الملكية الخاصة وقدسيتها. وقد شهدت فاية

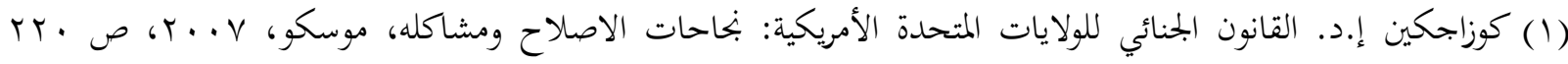
(باللغة الروسية). (T) يمكن الإطلاع باللغة الروسية على كثير من القوانين العقابية الأجنبية (غير العربية) على الموقع الالكتروني: /http://www.twirpx.com/files/law/criminal/foreign/codes (r) أشجوف إ.ن.، سيلياكوف ن.أ، التشريع الجنائي لدول الإتحاد الأوربي، موسكو، ه . . Y، ص ع V (باللغة الروسية). 
القرن العشرين إلغاء هذه العقوبة في الأغلبية الساحقة من البلدان، وهذه العملية مستمرة بشكل كبير في الوقت

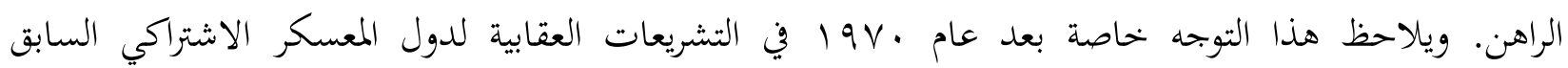

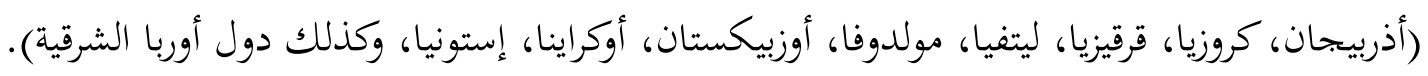

خامساً: إنتشار بدائل العقوبة المقيدة للحرية: لقد طرح الفقه الجنائي الأوربي في النصف الثاني من القرن التاسع

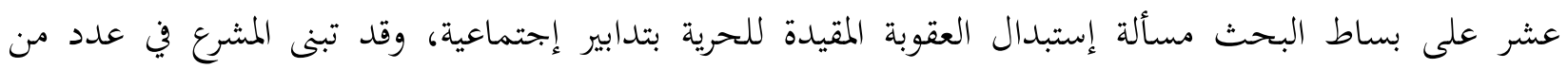
التشريعات العقابية الأوربية ذلك. الا إن تطبيق ذلك على نطاق واسع لم يتحقق الا في غاية القرن العشرين، وفي

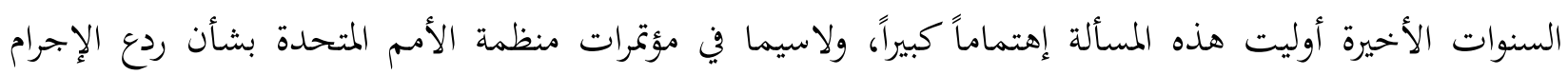

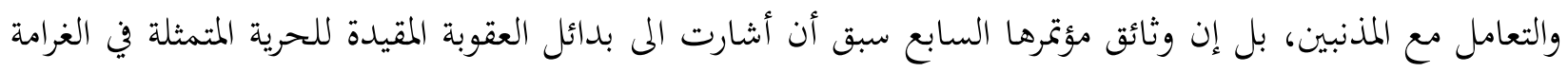

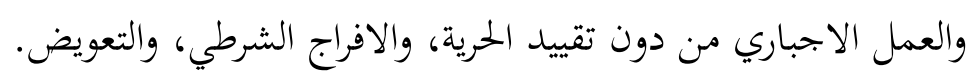

وفي السنوات العشرين الأخيرة ظهرت في التشريعات العقابية بدائل جديدة للعقوبة المقيدة للحرية مثل: العمل الاجتماعي (العمل للمنفعة الاجتماعية)، والحجز على الحرية، والاحتجاز المنزلي، والحجز المرحلي.

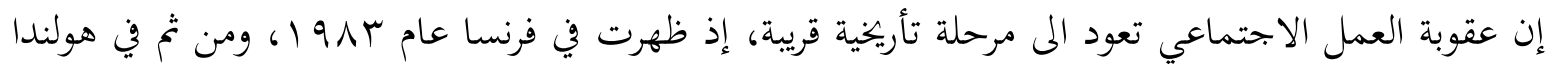

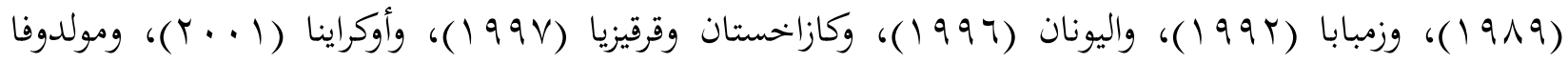

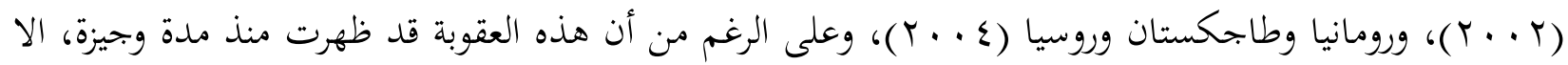

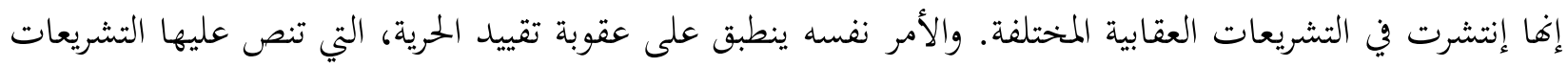

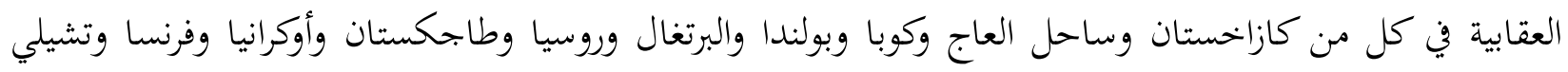
وغيرها.

وتعد عقوبة الحجز المرحلي مماثلة لعقوبة الحجز على الحرية، فهي تعني تمضية العقوبة المقيدة للحرية بصورة جزئية (في أيام العطل)، إذ تستهدف هذه العقوبة الحفاظ على العلاقات الطبيعية للمدان بها من ناحيتي الأسرة والعمل. وتنص عليها التشريعات العقابية في ألبانيا، والبرازيل والمكسيك والبرتغال والولايات المتحدة الأمريكية وفرنسا وإستونيا وجنوب أفريقيا وغيرها.

ويعد الاحتجاز المنزلي تدبيراً عقابياً جديداً بدأ بالظهور في السنوات الأخيرة في عدد قليل من البلدان، ومنها بوليفيا وإنكلترا وإسبانيا وكولومبيا والمغرب والولايات المتحدة الأمريكية وتركيا والفيلبين وغيرها. 
إصلاح قانون العقوبات ومستلزمات إقامة الحكم الرشيد

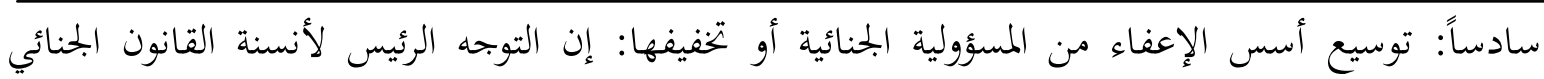

والسياسة الجنائية ينحصر في البحث عن مناهج بديلة ومناسبة للبت في النزاعات الجنائية، التي تمكن من جهة من إستبدال العقوبة المقيدة للحرية ببدائل عنها، وفي تجنب اللجوء الى القضاء من جهة ثانية.

وقد بدأ (التصالح مع البمنى عليه) بوصفه أساساً للإعفاء من المسؤولية الجنائية يجصل على إعتراف واسع في مختلف دول العالم بوصفه من بدائل السياسة الجنائية التقليدية، وذلك من خحلال مذهبين، أولمما (العدالة التصالحية)، وثانيهما (الوساطة). وينحصر جوهر المذهب الأول في إن الوظيفة الأساس للعملية الجنائية لا تنحصر في معاقبة المذنبين فقط، بل وكذلك في إعادة حقوق المجنى عليه التي إنتهكتها الجريمة، وكذلك في إعادة العلاقات الاجتماعية المنتهكة الى نصابها أيضاً. أما (التسوية) فتنحصر في تعزيز مكانة المجنى عليه في الاجراءات الجنائية، ومنحها صفة مدنية.

وشهدت السنوات الأخيرة إنتشاراً للإجراءات التصالحية في تطبيقات عديد من الدول مثل أستراليا وبلجيكا وإنكلترا والولايات المتحدة الأمريكية وفرنسا وهولندا وكندا وألمانيا وغيرها.

وعلى الصعيد نفسه تطور مفهوم (الدفاع الشرعي)، إذ لا يساءل جنائياً أو يعفى من المسؤولية الجنائية بشكل كامل في حالة (بحاوز حدود الدفاع الشرعي)، أو لا يعد بحاوزاً إرتكاب المدافع فعله نتيجة التدخل أو الهياج النفسي العنيف أو الخوف أو الفزع أو ما شابه، كما يلاحظ هذا في التشريعات العقابية في النمسا وبلغاريا والنرويج واليونان وألمانيا والدانمارك وجمهوريات يوغسلافيا السابقة وكوبا وكازاخستان وغيرها. وقد نصت المادة V من قانون العقوبات الروسي (حسب تعديل ب . . ץ) على إن فجائية الاعتداء يمكن أن تكون أساساً لتكييف واقعة الدفاع بوصفها بتحاوزاً لحدود الدفاع الشرعي عندما (لا يتمكن المدافع من تثمين درجة خطورة الاعتداء وطبيعته). وفي السنوت الأخيرة إنتشر في التشريعات العقابية مفهوم (سلامة العقل المحدودة) المعروف منذ النصف الأول من القرن التاسع عشر، وذلك كأساس لتخفيف المسؤولية الجنائية، كما في تشريعات دول الاتحاد السوفيتي السابق ودول أوربا الشرقية والبرتغال وأثيوبيا.

سابعاً: تطور التدابير المتخذة أزاء الأحداث: لقرون عديدة عان الأحداث (بل والصغار أيضاً) من قساوة العقوبات المتخذة ضدهم، ففي بداية القرن التاسع عشر، وفي دولة متحضرة مثل إنكلترا كان يمكن أن يتعرض الصغير لعقوبة الإعدام في حالة سرقة قطعة خبز. الا إنه في النصف الثاني من القرن التاسع عشر تغير هذا الموقف في القانون الأوربي والأمريكي، إذ بدأ الإعتراف وبشكل واسع بأهمية وجود نظام خاص من العقوبة بالنسبة للأحداث، يتميز بتخفيف صرامة العقوبة أو إستبدال العقوبة بتدابير ذات طبيعة إصالاحية وتربوية. 
وقد تطور هذا الموقف الإنساني أزاء الأحداث في النصف الثاني من القرن العشرين، وذلك إرتباطاً بصدور عديد من الاتفاقيات الدولية المتعلقة بحماية حقوق الطفل. ويف ضوء ذلك، بات نظام التدابير الخاص يحظى بدعم

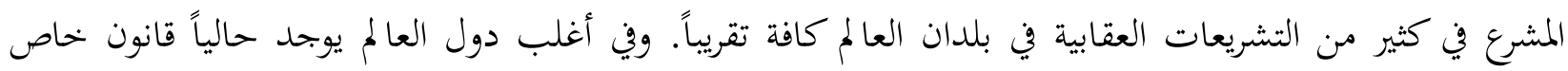

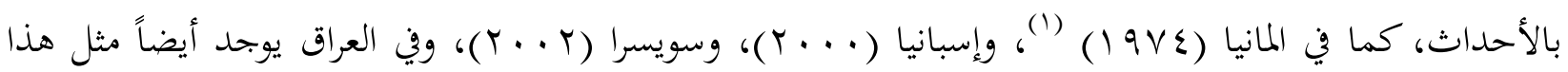

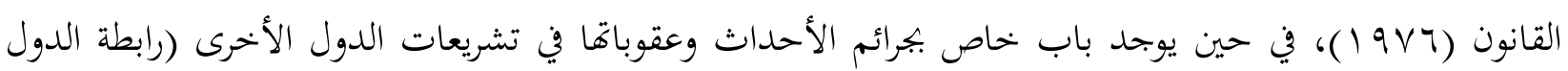
المستقلة، وجمهوريات يوغسلافيا السابقة وبلغاريا والمحر وفيتنام وهولندا ورومانيا وأثيوبيا وغيرها).

ثامناً: الحد من العقاب (شطب أنواع من الحرائم): في السنوات الخيرة من القرن العشرين تم إستبعاد عديد من

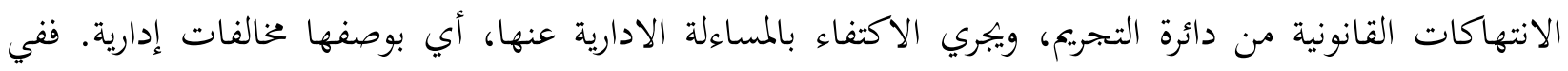

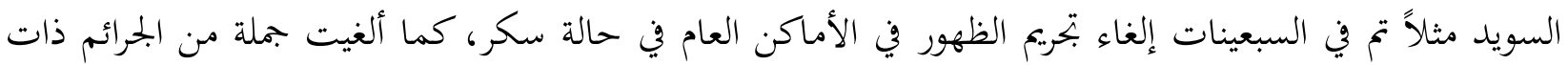

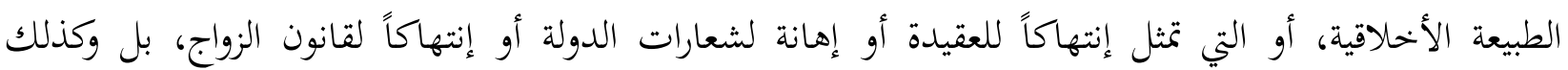
(「) السرقات البسيطة.

وقد طرأت مثل هذه التعديلات في كثير من التشريعات العقابية في مختلف دول العالم، ومن الجرائم التي شطبت تلك المرتبطة بالعلاقات الجنسية المثلية والإجهاض والسرقات البسيطة والتسول والحيانة الزوجية والجرائم الدينية

$$
\text { والمنشورات الإباحية. }
$$

ويلاحظ على صعيد التشريعات في رابطة الدول المستقلة مثلاً إلغاء كثير من الجرائم في غاية الثمانينات، وذلك

إرتباطاً بالتحولات الاجتماعية الطارئة فيها.

\section{المطلب الثاني \\ توسيع دائرة التجريم}

لقد أدى تطور البحتمع البشري وتعقد أشكال التنظيم الاجتماعي وظهور أنواع جديدة من النشاط الاقتصادي

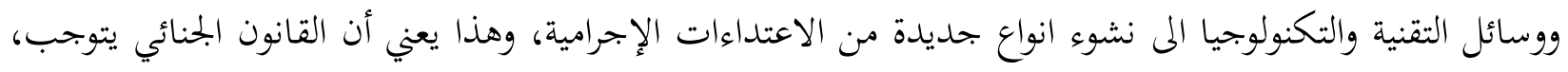

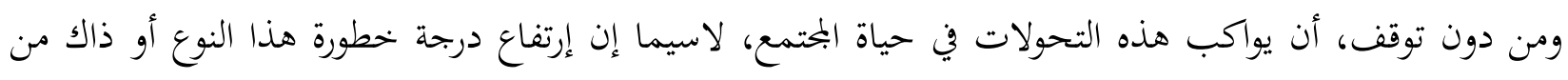
الجرائم يكون حصيلة لتضافر عدد من العوامل في آن واحد. وخير مثال على هذا الارهاب، فمن المعلوم إن جذوره

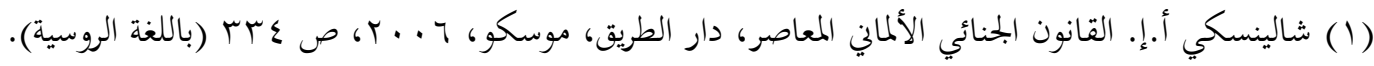

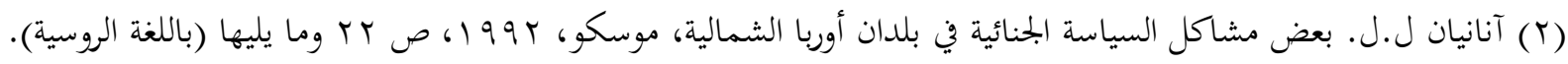




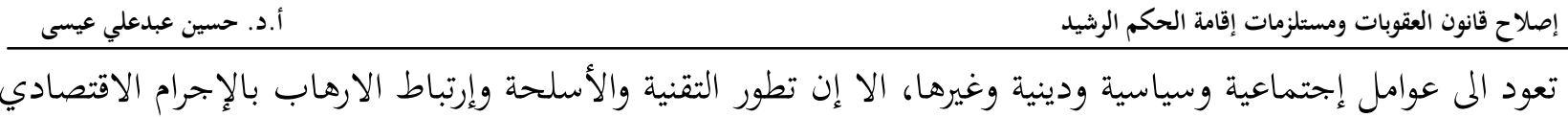
المنظم رفع الى حد كبير من درجة خطورة هذا الإجرام المستحدث.

إن بحريم الوقائع الجحيدة لا يتعلق بباب معين في القسم الخاص من التشريع العقابي، إذ إنه شمل أبوابه كافة، بل وأدى الى إستحداث أبواب جديدة لم تكن معروفة من قبل، بشأن الجرائم البيئية أو المعلوماتية مثلاً. ويلاحظ أن السنوات الثلاثين الأخيرة شهدت ظهور أنواع جديدة من الجرائم المرتبطة بالارهاب والجريمة المنظمة والجرائم الاقتصادية وغسيل الأموال والفساد والبيئة، وجرائم الحاسوب والمنشورات الإباحية المتعلقة بالأطفال والخطر النووي والاشعاعي والتقنية الطبية، التي يستحسن أن يضمها المشرع العراقي الى أحكام قانون العقوبات رقم (111 (1) لعام 979 16 وسنتطرق اليها بائياز:

أولاً: جرائم الارهاب: في القانون الجنائي المعاصر يتصف بتحيم هذه الجرائم بطابعه الشامل، إذ إن بحريم الارهاب يتضمن بتريم الارهاب وخطف الرهائن وخطف الطائرات والبلاغ الكاذب عن العمل الارهابي. ومن المعلوم إن الارهاب لا يعد جريمة جديدة بالنسبة لكثير من الدول، إذ كان يعد مشكلة إجتماعية كبيرة في القرن التاسع عشر، الا إنه حتى منتصف القرن العشرين كان يتصف بطبيعة فردية، إذ كان العمل الارهابي يطال عادة إحدى الشخصيات في الدولة، لذلك كان يكفي إعتماد الأحكام التقليدية في القانون الجنائي لمواجهته، وفي عدد من الدول تم تجريم عدد من صوره المتمثلة في قتل رئيس الدولة أو الشروع في ذلك. (1) ولكن مع تطور التقنية الحديثة والتغييرات السياسية في العالم في الستينات بدأ الارهاب يتخذ صوراً جديدة وأكثر خطورة ما إستدعى التدخل الفاعل للمشرع في مواجهتها، سواءً على الصعيد الدولي أم الداخلي. ففي عام • و ا أقرت إتفاقية لاهاي لمكافحة الاستيلاء غير المشروع على الطائرات، وفي عام IVI I إتفاقية مونتريال لمكافحة الأفعال غير المشروعة ضد أمن الطيران المدني، وفي عام 1 أم البروتوكول المتعلق بأعمال العنف غير المشروعة في المطارات الدولية. ويف التسعينات أقرت قواعد خاصة بشأن المسؤولية عن القرصنة الجوية وأدرجت

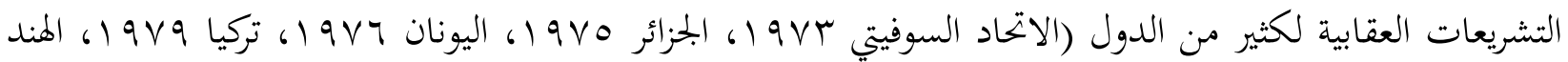
. (199. (1919 ) وبالتزامن مع بتريم القرصنة الجحوية، تم في السبعينات تجريم جملة من الجرائم ذات الطبيعة الارهابية في تشريعات

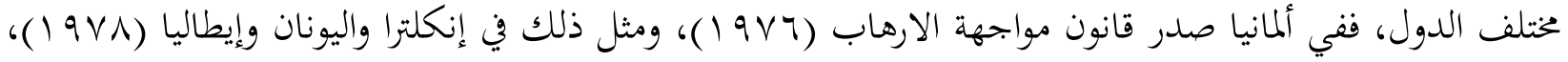

(1) نصت م/ r ا T عقوبات عراقي على عقوبة الإعدام عن قتل رئيس الجمهورية عمداً (فقرة ()، ويعاقب بالسجن المؤقت عن الإعتداء الذي لا يبلغ درجة القتل عمداً أو الشروع في ذلك (فقرة ب)، وكذلك على إتخاذ العقوبات نفسها بالنسبة لقتل رئيس دولة 


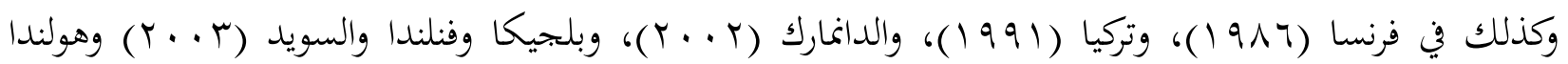

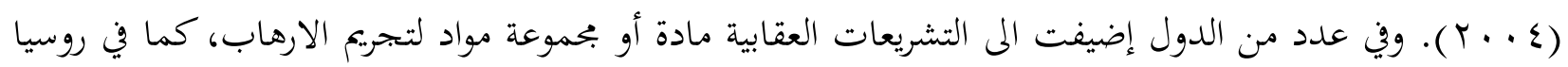

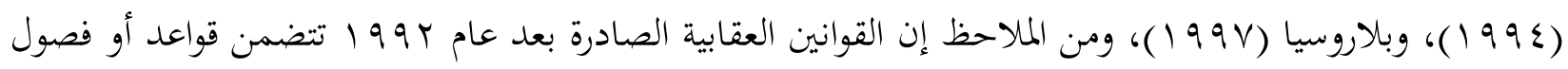
خاصة بالمساءلة الجنائية عن النشاط الارهابي.

إن إصلاح التشريعات العقابية في السنوات الأخيرة يسير في إبتاه تجريم الصور الجديدة للنشاط الارهابي، إذ إذاب

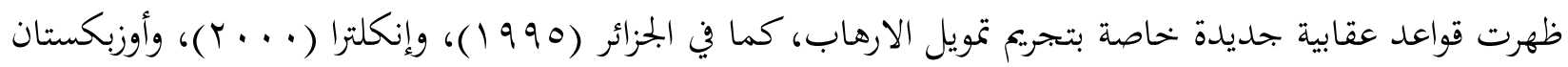

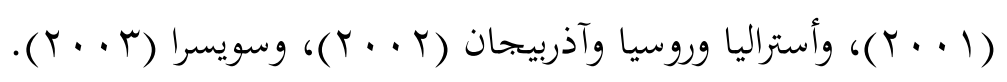

ويوجد هناك توجه لتجميع القواعد العقابية الخاصة بمواجهة الارهاب في نطاق قانون واحد، ففي

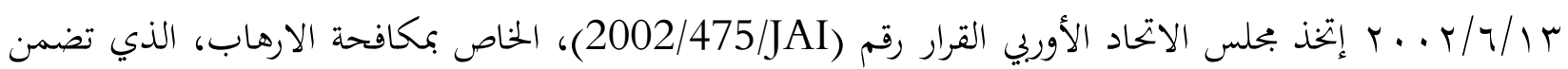
تحديد مفهوم الارهاب وصوره. وقد إستدعى إزدياد خطورة الارهاب في القرن الحادي والعشرين تدخل المشرع فصدرت عديد من التشريعات

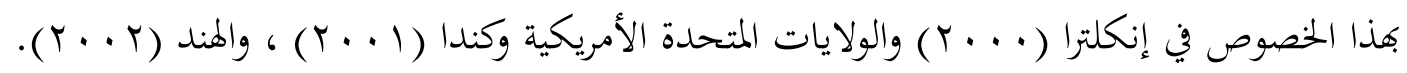
ثانياً: الاجرام المنظم: ظهر الاجرام المنظم وإتخذ نطاقاً واسعاً في الولايات المتحدة الأمريكية وإيطاليا في النصف الأول من القرن العشرين، الا إن مواجهته حتى الربع الأخير من القرن نفسه إستندت المى القواعد الجنائية المتعلقة بالمساهمة والاتفاق الجنائي.

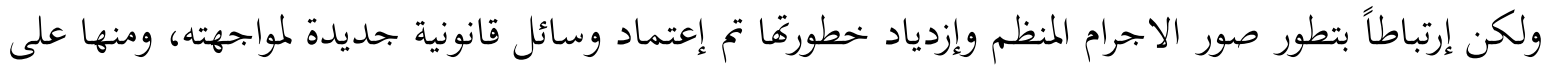
صعيد التشريعات العقابية، ففي بداية السبعينات أخذ المشرع بإيقاع المسؤولية الجنائية عن واقعة إنشاء المنظمة الاجرامية أو المشاركة فيها، كما ظهرت قواعد جنائية تحدد مفهوم المنظمة الإجرامية وتعاقب على المشاركة في نشاطها،

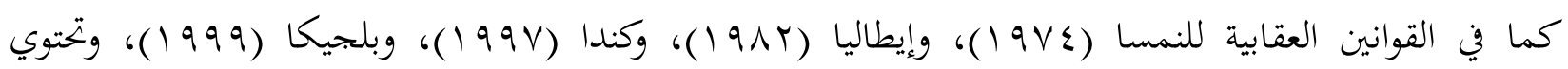
القوانين العقابية الصادرة بعد عام بو 99 العلها تقريباً على قواعد مماثلة.

وأخذ المشرع في عدد من الدول بنهج إصدار قوانين خاصة بكافحة الاجرام المنظم، وذلك بإدراج التدابير

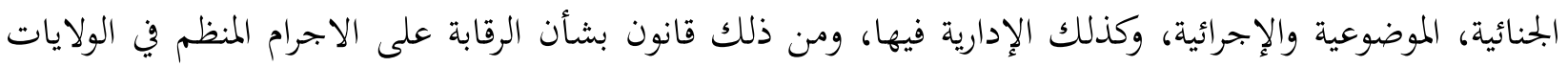

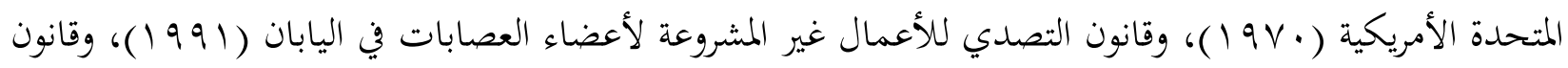

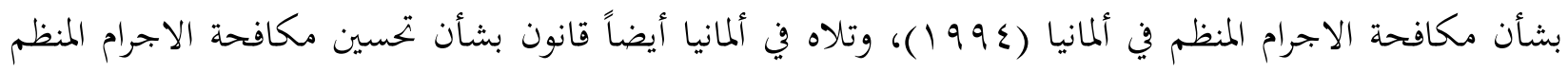

$$
\text { (1991)، وقانون ردع الاجرام المنظم في جنوب أفريقيا (1991 (1). }
$$


إصلاح قانون العقوبات ومستلزمات إقامة الحكم الرشيد

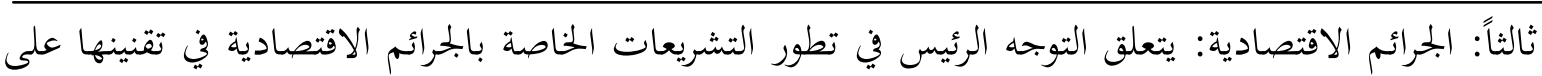

الصعيد العالمي، وينبع أساس ذلك من الاصلاحات السياسية والاجتماعية والاقتصادية الجذرية التي طرأت في النصف الثاني من الثمانينات، ذلك إن القواعد الجنائية الجلديدة المكرسة لمكافحة الجرائم الاقتصادية الجديدة إنما إستهدفت حماية إقتصاد السوق. لذلك شهدت التشريعات العقابية، لاسيما في الدول الاشتراكية السابقة، تعديلات جوهرية في الابواب والفصول الخاصة بالجرائم الاقتصادية، وهذا ينطبق على فيتنام والصين ولاؤوس ودول التوجه الاشتراكي السابقة.

وفي عدد من الدول تطلبت مواجهة هذه الجرائم الاعتراف بالمسؤولية الجنائية للأشخاص الإعتبارية، هذا على الرغم من إن ذلك لم يكن جديدأ بالنسبة لتشريعات عدد من الدول مثل إنكلترا والولايات المتحدة الأمريكية وأستراليا، الا إن تطبيقه إتخذ نطاقاً عاماً في السنوات الأخيرة، فادرج في التشريعات العقابية لكل من هولندا

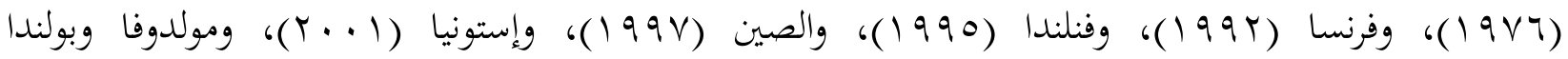

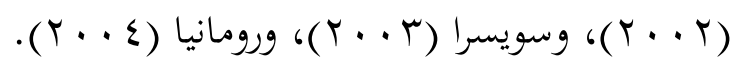

وأخذ عدد من الدول بموقف وسط، إذ لا تعترف تشريعاما العقابية بالشخص الإعتباري بوصفه فاعلاً للجريمة، ولكن يمكن أن تتخذ أزاءه مختلف التدابير العقابية كما في النمسا وألبانيا وإسبانيا والمكسيك وبيرو.

رابعاً: غسيل الأموال: ظهر الاهتمام الدولي بمسألة غسيل الأموال في البدء إرتباطاً بالاتحار بالمخدرات، وذلك لأن إنتقال (حركة) المال عبر الحدود يعد ميزة للعمليات المرتبطة بغسل الأموال المتحصلة من الاتجار بالمخدرات. لذلك ففي فيينا أقرت في عام 1 إ إتفاقية الأمم المتحدة بشأن مكافحة الإبحار غير المشروع بالمخدرات والمؤثرات العقلية، التي تضمنت تحديداً لغسيل الأموال المرتبط بالمخدرات بوصفها جريمة. ومن أهم المواثيق الدولية أيضاً الصادرة على الصعيد نفسه: إتفاقية بحلس أوربا الخاصة بضبط الايرادات المتحصلة من النشاط الاجرامي وإظهارها وضبطها ومصادرقا، التي اقرت في 1/1/ / / 19 1 في ستراسبورغ، وكذلك القانون النموذجي بشأن غسيل الأموال المتحصلة من المخدرات، الذي وضعته منظمة الأمم المتحدة عام ب99 1 ـ.

وبدءاً بعام • 99 ا أجرت الأغلبية الساحقة من الدول، وبضمنها الدول المتطورة تعديلات في تشريعاتما العقابية لمواجهة غسيل الأموال، وبإستثناء عدد من التشريعات العقابية، يلاحظ أن التشريعات العقابية التي صدرت بعد عام (1) 199 .

خامساً: جرائم الفساد: منذ عام •99 99 هناك توجه في التشريعات العقابية بعد الفساد ظاهرة خطيرة وبتعدي نطاقها حدود الدولة، بل إها تعد أحد عناصر الاجرام المنظم الوطني والعابر للحدود، ما إستدعي إهتمام المحتمع (1) من ذلك مثلاً م/اب؟r من قانون العقوبات الألماني النافذ. 
الدولي لمواجهته. ففي عام 997 أصدرت منظمة الأمم المتحدة إعلان بشأن مكافحة الفساد والرشوة في الصفقات التجارية الدولية، وفي عام لو99 إتفاقية مكافحة رشوة موظفي الدول الأجنبية لدى إجراء صفقات العمل الدولية،

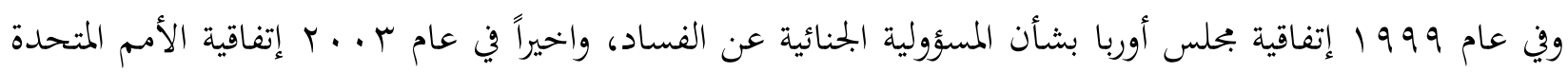
بشأن مكافحة الفساد.

إن إتفاقية مكافحة الفساد لعام ب . . ب تتضمن تجريم رشوة الموظفين العموميين الوطنيين وكذلك تجريم رشوة

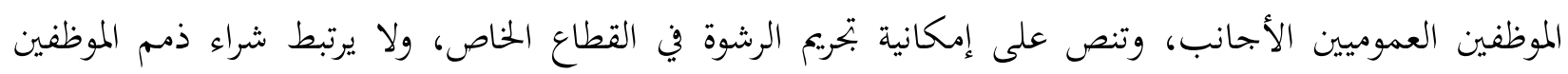

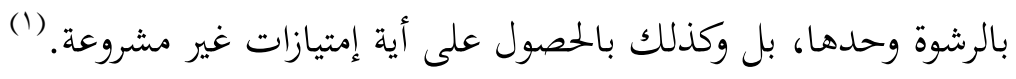

ومن المنتظر أن بتري في السنوات المقبلة عملية بتحيم الفساد الدولي بشكل متسارع وبصفتها جريمة مستقلة قائمة بحد ذاتها، إذ ظهرت أركان هذه الجريمة في التشريعات العقابية لاستراليا والنمسا وإنكلترا وبلجيكا وبلغاريا وكندا هولندا والنرويج وفرنسا والسويد وسويسرا وغيرها.

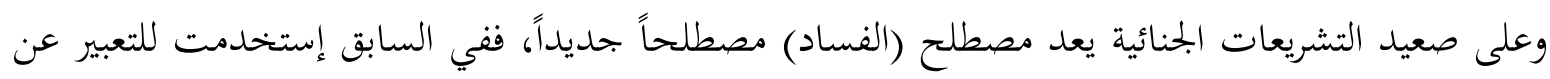

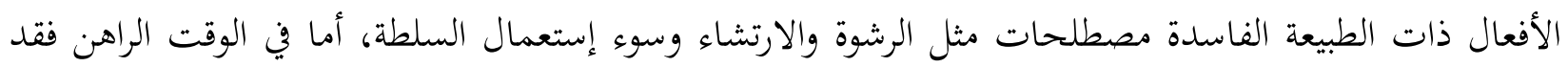

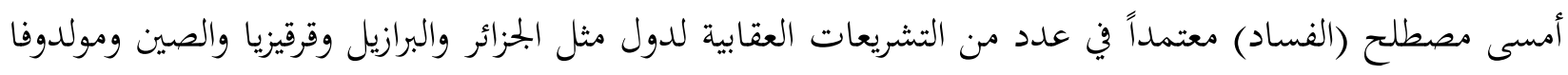
وفرنسا وغيرها.

ويعد الاتحار بالنفوذ (إستغلال النفوذ) من صور جرائم الفساد التي تنص عليها التشريعات العقابية في الجزائر والمحر وكولومبيا والمكسيك ومولدوفا وبيرو وفرنسا.

سادساً: جرائم البيئة: في السنوات الأخيرة طرأت تطورات في السياسة الجنائية إرتباطاً بأن العلاقات البيئية تحولت الى موضوع للحماية الجنائية، ويعود هذا التوجه في السياسة الجنائية الى السبعينات. ففي أغلبية القوانين العقابية

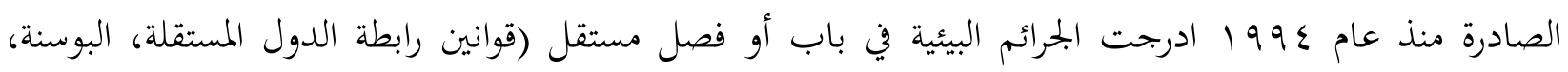
الهرسك، فيتنام، إسبانيا، كولومبيا، منغوليا، بولندا وغيرها).

وفضلاً عن الجرائم البيئية التقليدية ظهر الاجرام البيئي المنظم المرتبط بالتخلص من مخلفات الانتاج المشعة

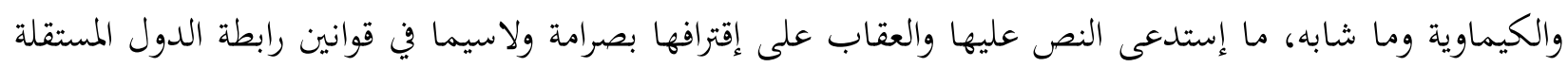
والصين وإستونيا والمجر وبلغاريا وجمهوريات يوغسلافيا السابقة وغيرها.

(1) للتفاصيل حول ذلك: كوسار سعيد غفور، آليات إنفاذ إتفاقية مكافحة الفساد لسنة ب. . r، رسالة ماجستير، كلية القانون والسياسة، جامعة السليمانية، 1 ا • ب، الفصل الثاني. 


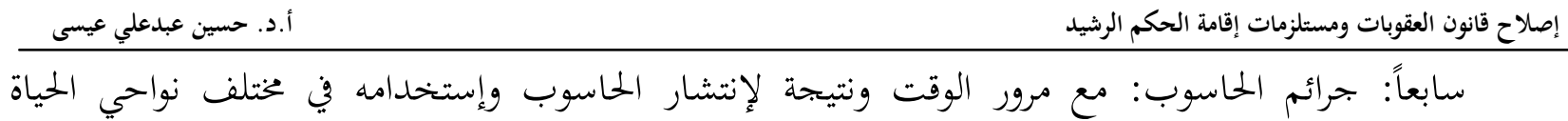
الاجتماعية أخذات جرائم الحاسوب تولى أهمية أكبر. ومن الملاحظ إن الجوانب الأساسية في المحتمع وبضمنها المالية باتت تعتمد على شبكات الحاسوب، ما أدى الى إنتشار جرائم الحاسوب، لذلك فقد شهد العقدان الأخيران تطويراً للقواعد الجنائية فيما يتعلق بمواجهة هذه الجرائم وردعها.

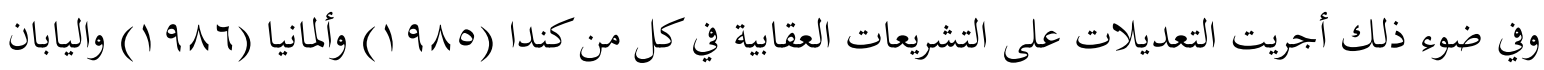

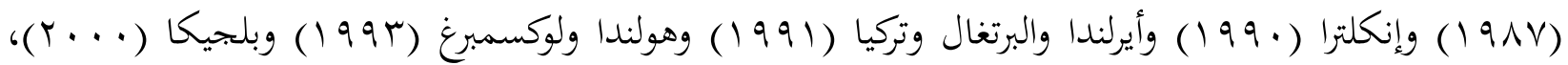
وتتضمن القوانين العقابية الصادرة بعد عام ب9919، وبضمنها قوانين رابطة الدول المستقلة ودول البلطيق قواعد وفصولاً خاصة بهذه الجرائم.

ثامناً: الاستغلال الجنسي للأطفال: إن الميزة الرئيسة للقانون الجنائي المعاصر تتمثل دون شك في إيلاء العناية الفائقة بمصالح الصغار، ولاسيما أزاء مختلف أشكال العنف والاستغلال الجنسي وما شابه. وإرتباطاً بتطور التقنية المعلوماتية أوليت في السنوات الأخيرة مسألة (المنشورات الإباحية) إهتماماً كبيراً، فهي تعد جريمة ذات طبيعة دولية، وتنبع إلتزامات الدول بإتخاذ التدابير العقابية المناسبة من البروتوكول الملحق (البروتوكول التكميلي) بإتفاقية حقوق الطفل المتعلقة بالاتحار بالأطفال ودعارة الأطفال والمنشروات الاباحية الخاصة بهم، الذي اقرته الجمعية العامة للأمم (1) (المتحدة.

إن ضرورة إدراج قواعد قانونية بشأن المسؤولية الجنائية عن المنشورات الاباحية للأطفال تنبع من إن المنشورات الاباحية العادية لا تعد جريمة في كثير من الدول أو إنما تعد جرائم تتصف بعقوبتها البسيطة.

ومع بداية . 99 19 ظهرت قواعد خاصة بصدد المنشورات الاباحية للأطفال في التشريعات العقابية لاستراليا والارجنتين وإسبانيا وايرلندا وروسيا وفرنسا والسويد وسويسرا وألمانيا واليابان وجنوب أفريقيا والفيلبين وغيرها. وفي نطاق مكافحة دعارة الأطفال يلاحظ إن هناك توجهاً نحو تشديد المسؤلية الجنائية عنها في التشريعات العقابية في إنكلترا وألمانيا وإيطاليا وكندا وفرنسا واليابان وفنلندا والنرويج وغيرها. وعلى الصعيد نفسه هناك توجه مماثل فيما يتعلق بالسياحة الجنسية المتعلقة بالأطفال في التشريعات العقابية لاستراليا وإنكلترا وكولومبيا ونيوزلندا والولايات المتحدة الأمريكية.

تاسعاً: الجرائم المرتبطة بالأمن النووي والاشعاعي: لقد أدى تطور التكنولوجيا وما يرتبط به من أخطار الى تطور التشريع الجنائي، ففي السنوات العشرين الماضية ظهرت قواعد جنائية لمواجهةالخطر الموجه ضد الأمن النووي 
والاشعاعي، ففي عدد من الدول أدرجت في التشريعات العقابية أركان هذه الجرائم، وخاصة في النمسا ورابطة الدول

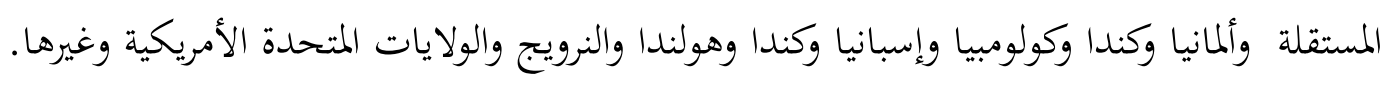

عاشراً: الجرائم الطبية: في السنوات الأخيرة بدأ بالظهور نمط جديد من الجرائم المستحدثة يمكن أن تطلق عليها

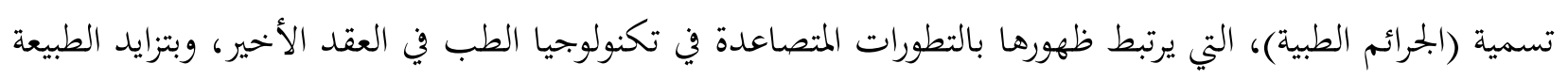

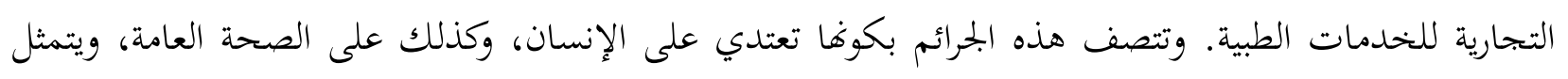

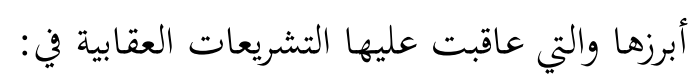

(أ) نقل الأعضاء البشرية والاتحار بها (رابطة الدول المستقلة، بلغاريا، إسبانيا، فرنسا، دول البلطيق، العراق،

$$
\text { وغيرها). }
$$

(ب) العمليات الجينية غير المشروعة (إسبانيا، كروزيا، البحر ، كولومبيا، السلفادور وغيرها).

(ت) إجراء التجارب الطبية على الانسان خلافاً للقانون (أرمينيا، البحر، أوكراينيا، فرنسا، إستونيا، سلوفاكيا).

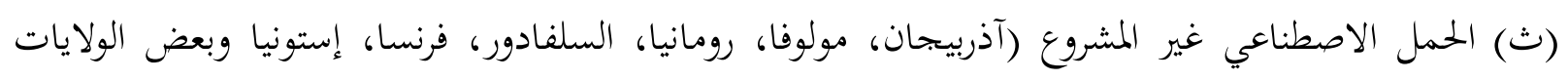

$$
\text { (ج) التعقيم الطبي غير المشروع (آذربيجان، ومولدوفا). }
$$

(ح) إستعمال الوسائل المحرمة في التشخيص والعلاج وكذلك الوسائل الدوائية المحرمة (آذربيجان).

\section{المطلب الثالث}

\section{تدويل القانون الجنائي}

يعود هذا التوجه في السياسة الجنائية المعاصرة الم التطور الكبير للقانون الدولي وتأثيره على تطور التشريعات

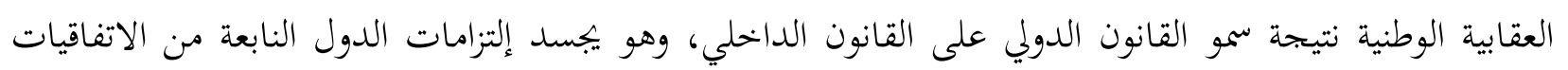
الدولية والمواثيق الدولية الأخرى.

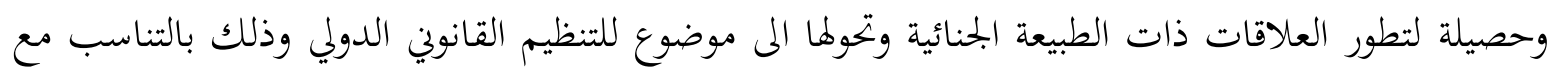

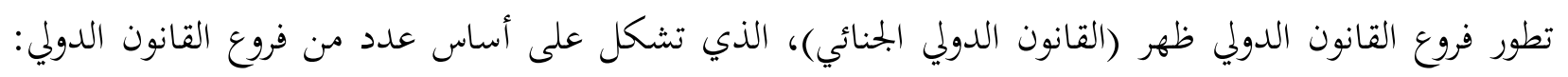

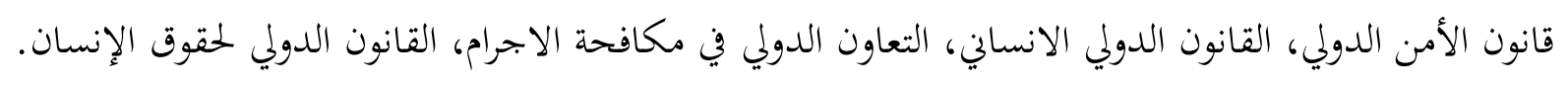
وفي الوقت الراهن، يتضمن القانون الدولي الجنائي نظاماً معقداً، يمكن أن يتوزع على النظم الفرعية الآتية: 
ا ب - القانون الدولي الجنائي بوصفه قانون المحاكم الجنائية الدولية.

r- القانون الجنائي الدولي بوصفه أحد فروع القانون الدولي العام، الذي ينظم التعاون الدولي في

مكافحة الاجرام.

r- القانون الجنائي الدولي بوصفه بحموعة من القواعد القانونية الدولية والداخلية، المحددة للعلاقة التبادلية بين النظم القانونية الوطنية بخصوص مسائل الإختصاص القضائي وتسليم الجمرمين والإعتراف بالأحكام

$$
\text { القضائية الأجنبية وغيرها (تنازع القوانين الجنائي). }
$$

فضلاً عن هذا، يلحظ أيضاً ظهور نظم فرعية للقانون الدولي الجنائي تتمثل في القانون الجنائي للإتحادات

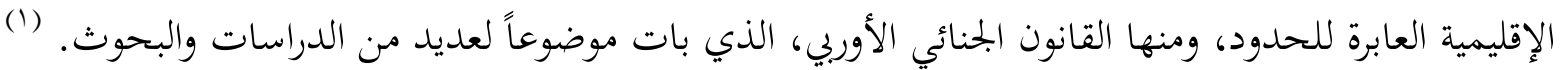

إن بدايات القانونالدولي الجنائي تعود الى المتطلبات التي طرحها التطبيق العملي في نطاق مكافحة الاجرام

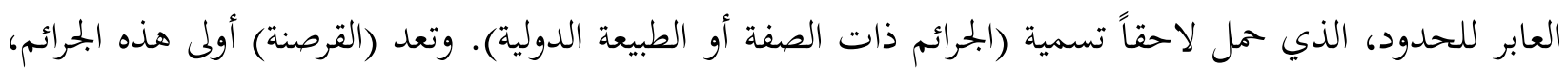
إذ أعترف بها العرف القانوين الدولي في القرن الثامن عشر، ومن ثم (الاتحار بالعبيد) على وفق قرار فيينا لسنة

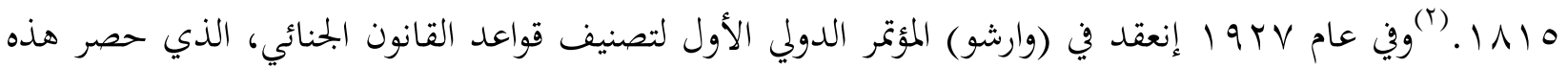
الجرائم في: القرصنة، تزييف العملة والاتحار بالعبيد والنساء والأطفال، المخدرات، المنشورات الإباحية، وكذلك الجرائم الجمائم

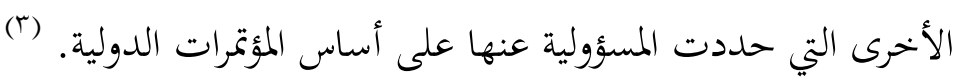

ومع إنتهاء الحرب العالمية الثانية أدرك البحتمع الدولي مثثلاً بالدول المنتصرة إن عدداً من الجرائم الوحشية ذات الطبيعة الجماعية تنطوي على تهديد للإنسانية جمعاء، وهي تخرج من الإختصاص القضائي لكل دولة حدة، وقد

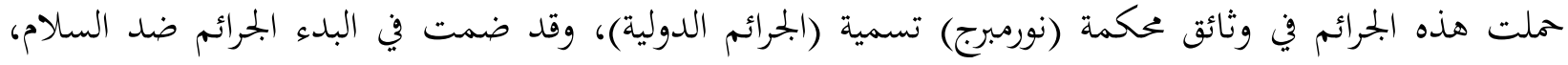
جرائم الحرب، والجرائم ضد الإنسانية، ومن ثم أضيفت اليها جرائم الإبادة الجماعية والفصل العنصري والإستعمار والإستعمار الجحديد والإيكوتسيد (التهجير) وتحنيد المرتزقة. وقد إحتوى النظام الأساس للمحكمة الجنائية الدولية ( 99 / / V/ V V) للجرائم الدولية. ويمكن القول إن هذه الوثيقة الدولية تعد على وجه العموم أول مدونة جنائية دولية.

(1) مثلاً: شجدانوف يو.ن. ليخافسكايا.إس. القانون الجنائي الأوربي، آفاق التطوير، دار العلاقات الدولية، موسكو، ا...

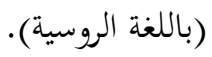

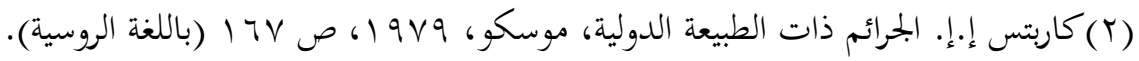

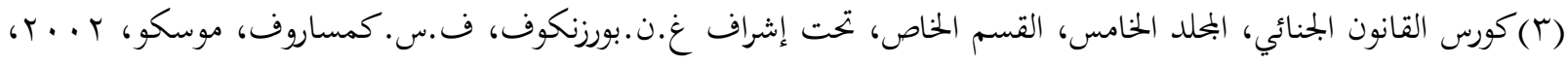


وفي خلال العقدين الماضيين تطور القانون الدولي الجنائي إرتباطاً بظهور صور جديدة من الجرائم العابرة

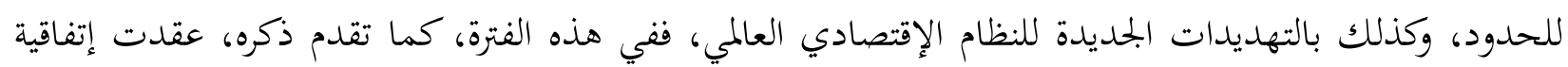

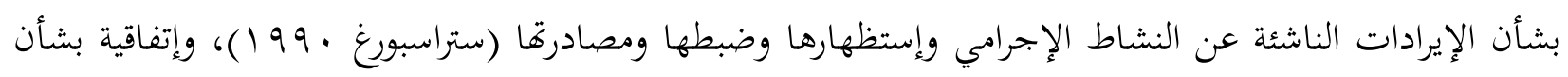
شراء ذمم موظفي الدول الأجنبية في صفقات العمل الدولية (1991 (1)، وإتفاقية بحلس أوربا بشأن المسؤولية الجزائية

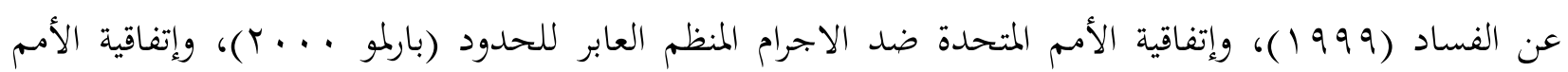

$$
\text { المتحدة لمكافحة الفساد (r. r. (Y). }
$$

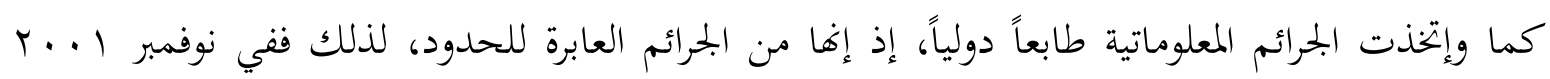

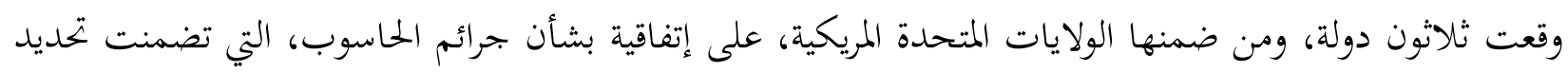

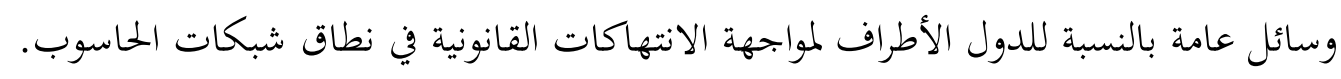

وتتضمن (الجرائم ذات الطبيعة الدولية) في الوقت الراهن عشرات الجرائم المتنوعة، ومن الملاحظ إها في تزايد

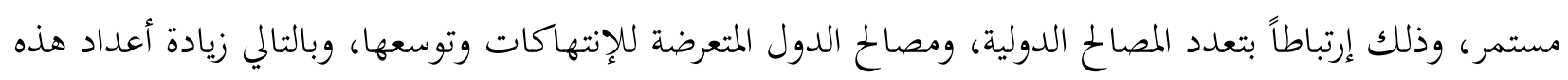
الإنتهاكات وتنوعها.

إن تطور القانون الدولي الجنائي لا يرتبط بتوسع نطاق الجرائم ذات الطبيعة الدولية فحسب، بل وكذلك بوجود

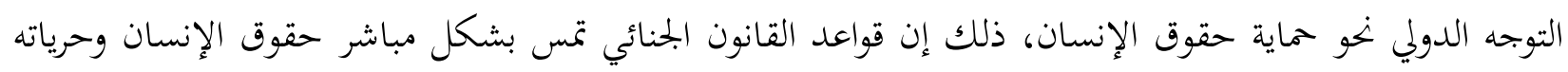

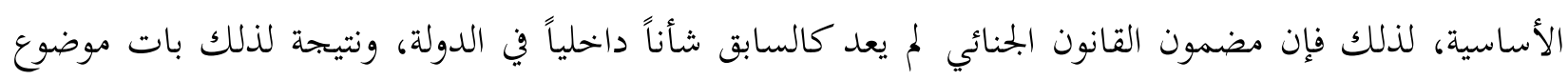

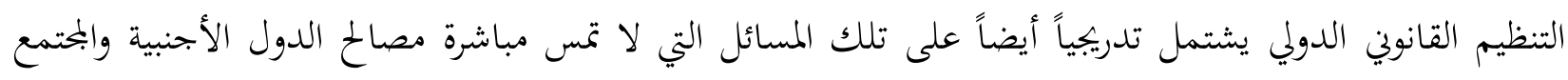

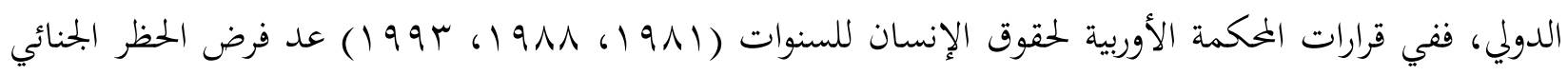

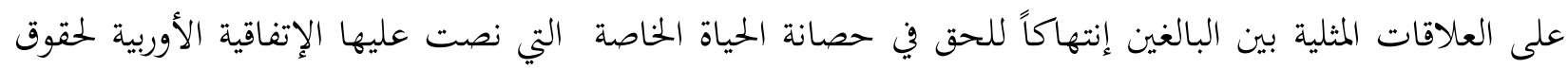
(الإنسان. (1)

وفضلاً عن تطور القانون الدولي الجنائي، كما تقدم، توسعت في السنوت الأخيرة فاعلية تطبيقه، إذ إن هذا

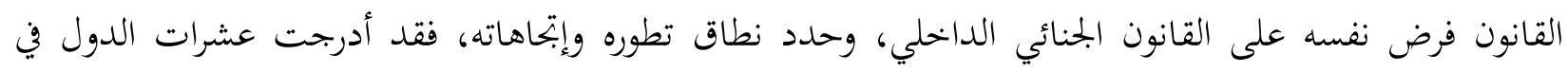

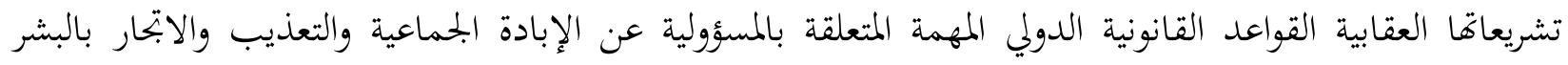
وغيرها، فالمشرع الوطني يسعى بذلك الى الإلتزام بتلك الالتزامات النابعة من المواثيق الدولية ذات الصلة، ولا يرتبط

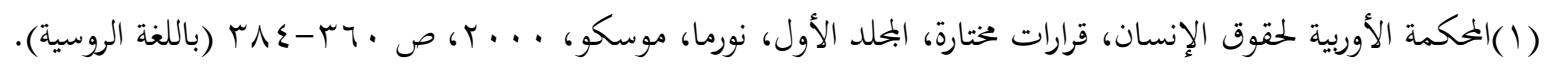




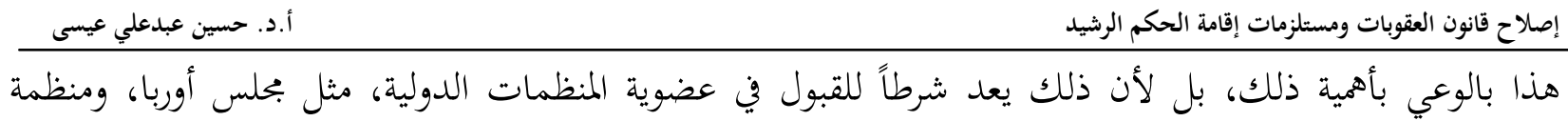
التجارة الدولية، وغيرها، وكذلك من أجل الحصول على المساعدات المالية من الدول المتطورة (المانحة).

ويجري إدماج قواعد القانون الدولي في التشريعات الداخلية، خاصة لدى إجراء الاصلاح العام للقانون الجنائي، فمنذ بداية عام • 99 19 يلاحظ إن أي مشروع لقانون العقوبات عند طرحه ينظر في مدى توافقه مع (المعايير الدولية) ما يستدعي كقاعدة إشراك الخبراء الأجانب وممثلي المنظمات الدولية في وضع المشروع. وبهذه الصورة باتت قواعد القانون الدولي الجنائي جزءاً لا يتجزأ من أي تشريع عقابي معاصر.

إن الصفة المميزة للقوانين العقابية كافة الصادرة حديثاً هو إحتواؤها كلها تقريباً على باب (فصل) خاص بالجرائم الدولية (رابطة الدول المستقلة، البلطيق، إسبانيا، منغوليا، مالي، بولندا، البرتغال، تركيا، فرنسا، أثيوبيا،

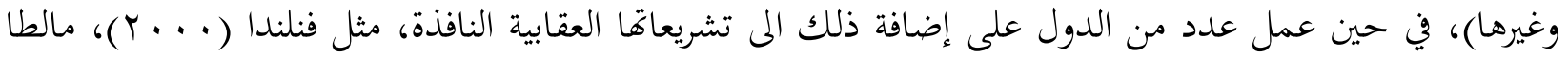

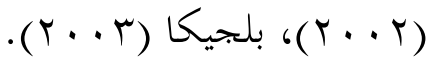

ويلاحظ إن عدداً من الدول أدرج هذه الجرائم في فاتحة القسم الخاص من قانون العقوبات، ما يدل على أهميتها بالنسبة للمشرع الداخلي، كما في (ألبانيا، لاتفيا، ليفيا، مولدوفا، بولندا، فرنسا، إستونيا، وغيرها). وقد عمل عدد آخر من الدول على إصدار تشريع عقابي خاص بهذه الجرائم، كما في إنكلترا وألمانيا وهولندا ونيوزلندا وجنوب أفيقيا وبروندي.كما عمل المشرع بشكل فاعل على إدراج الجرائم الأخرى التي نصت عليها الاتفاقيات الدولية في التشريعات العقابية الداخلية، ومن ذلك على سبيل المثال التعذيب والإبحار بالبشر.

إن إدراج التعذيب بوصفه جريمة قائمة بحد ذاتها، جنباً الى جنب الجرائم العنفية الأخرى، وبما يختلف جوهرياً عنها يرتبط بالمقام الأول بالاهتمام الخاص الذي أولاه المشرع الدولي لمسألة تحيم التعذيب، ففي الإعلان العالمي لحقوق الإنسان (1) (1))، نصت المادة (0) فيه على عدم تعريض أي شخص للتعذيب أو لأي عقوبة أو معاملة قاسية أو وحشية أو حاطة بالكرامة، بما يقلل من كرامته أو تعد قاسية أو غير إنسانية. وهذا المطلب بات قاعدة قانونية دولية نص عليها العهد الدولي بشأن الحقوق المدنية والسياسية، الذي أقرته الجمعية العامة للأمم المتحدة في

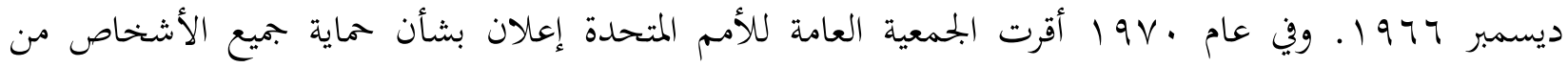
التعذيب واشكال المعاملة والعقوبة القاسية وغير الانسانية والمحقرة للكرامة، وفي ضوء هذه الإتفاقية عقدت في عام

(1) ع 19 الاتفاقية الدولية لمناهضةالتعذيب.

(1 ) هذه الوثائق الدولية متاحة على الموقع الألكتروني لمنظمة الأمم المتحدة: http://www.un.org/ar/documents/index.html 


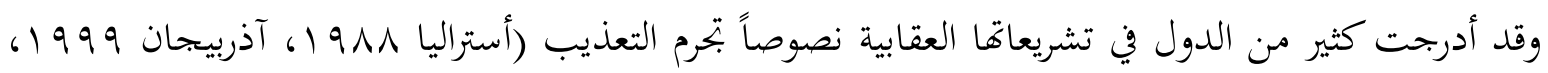

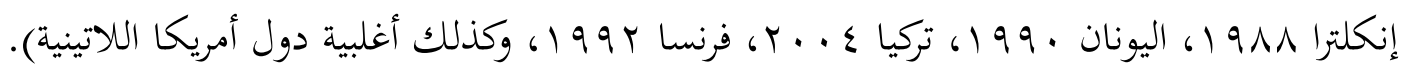

ويعد الابحار بالبشر من أقدم الجرائم التي تضمنتها الاتفاقيات الدولية، فأول إتفاقية دولية جاءت خاصة

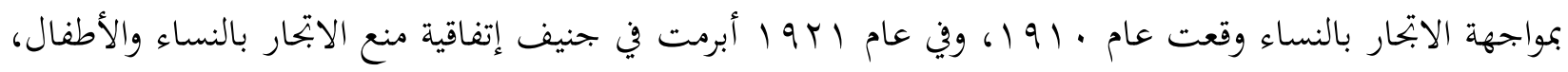

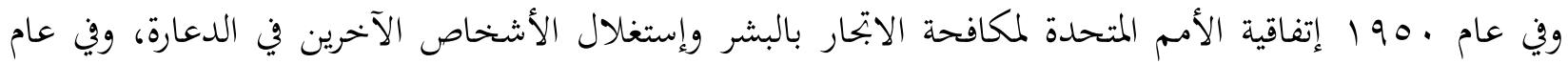

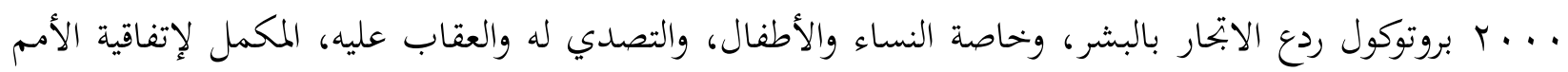

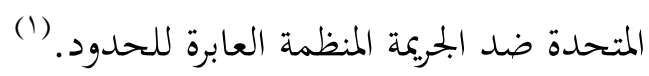
وعلى أساس ذلك تم في عديد من الدول تجريم الاتحار بالبشر في التشريعات العقابية، وخاصة في السنوات

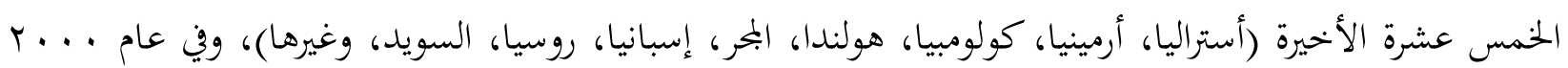

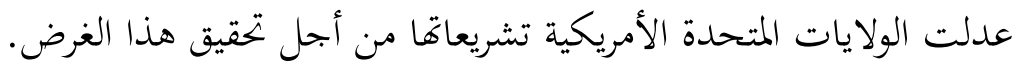
إن القانون الدولي الجنائي لا يؤثر في إصلاح أحكام القانون الجنائي فيما يتعلق بقسمه الخاص فحسب، بل

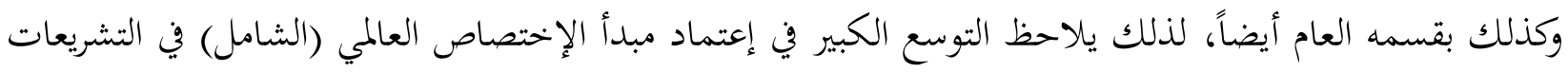
العقابية في السنوات الأخيرة.

لقد وضع هذا المبدأ بعد الحرب العالمية الثانية، وجاء معبراً عن إتفاقيات جنيف الأربع لعام 9 الع 1. وهو

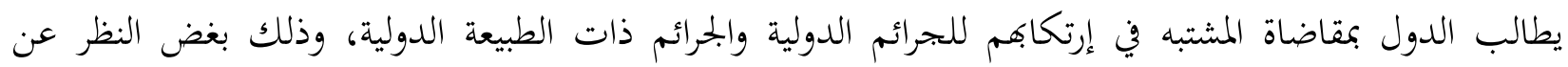

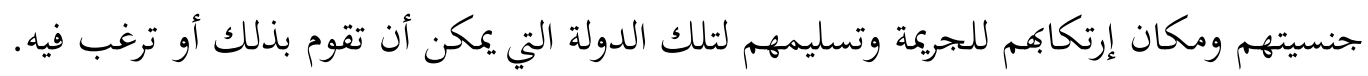
وبصرف النظر عن الصعوبات الكبيرة في تطبيقه فإن هذا المبدأ يستخدم بصورة فاعلة في التطبيقات، وخاصة

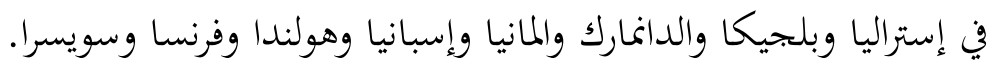
إن خصائص تأثير القانون الدولي الجنائي على تطور القسم العام للقانون الجنائي تنحصر في إن هذا التأثير يتحقق بمساعدة القواعد ذات الطبيعة الايصائية (التوصيات) أي ما يسمى بالقانون (الناعم)، ومن ذلك على سلى سبيل

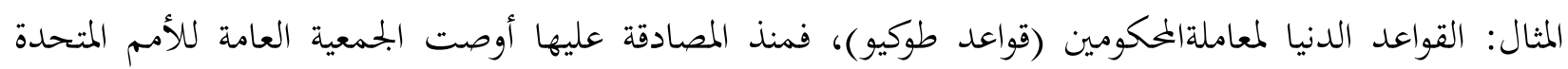

(1) ساكار على محمود، الإتحار غير المشروع بالأعضاء البشرية، دراسة تحليلة مقارنة، رسالة ماجستير، كلية القانون والسياسة، 
بتجسيدها قانون العقوبات ومستلزمات إقامة الحكم الرشيد الصعيد الداخلي والإقليمي والدولي "مع مراعاة الظروف السياسية والاقتصادية والاجتماعية والثقافية (1) بلبلدان (1)

إن تدويل القانون الجنائي يحقق التوافق بين التشريعات العقابية، أي التقارب على أساس الأحكام القانونية الدولية العامةفيما يتعلق بمتطلبات التعاون الدولي، وبطبيعةالحال، يتعلق الأمر بالجانب الخاص بمضمون التنظيم الجنائي، وليس بجوهره، وذلك لإختالاف النظم القانونية أحدها عن الآخر. 


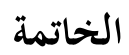

من خحلال هذالبحث يمكن التوصل الى الإستناجات والتوصيات الرئيسة الآتية:

\section{أولاً: الإستنتاجات:}

ا- إن الحكم الرشيد يقوم على دعائم، تحتل (سيادة القانون) مكانة خاصة فيها، وهو ما يجسد مكانة القانون في المجتمع، ودوره في إستقراره وتعزيز التحولات السياسية والاجتماعية والاقتصادية التي يعيشها، وعلى هذا الصعيد تتجلى الأهمية الكبيرة لقانون العقوبات في ذلك من حيث حمايتها من الاعتداءات الواقعة عليها، وكفالة حقوق أفراد البحتمع وحرياقم الأساسية، التي تنص عليها الدساتير والقوانين ذات الصلة. ץ- إن قانون العقوبات، شأنه شأن القوانين الأخرى، يمكن أن يتضمن ثغرات، منها ما يكون حصيلة حصيلة لعملية سنه، ومنها ما يرتبط بالتحولات الاجتماعية والاقتصادية والسياسية، نتيجة لتطور المجتمع صوب بناء دعائم الحكم الرشيد وتعزيزها، وكذلك منها ما يتعلق بالتطور الجاري على صعيد السياسة الجنائية في مواجهة صنهة

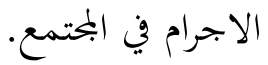

r- إن التطورات الجارية على صعيد السياسة الجنائية، وتحلياتما المعاصرة، التي إنعكست في التشريعات العقابية الحديثة، تشير الى تركيزها على محاور رئيسة ثلاثة هي: أنسنة القانون الجنائي، وتوسيع دائرة التجريم، وتدويل القانون الجنائي، وهي التي يتوجب أن بحد لها أنعكاساً في عملية الاصلاح المنتظر تحقيقها بالنسبة لقانون

$$
\text { العقوبات العراقي رقم (111) لعام } 11979 \text { العي } 119
$$

ع - تعد أنسنة القانون الجنائي من أهم التوجهات وأقدمها في السياسة الجنائية المعاصرة، وتعمل الدول كافة على أن تعكس تشريعاها العقابية ذلك، لاسيما في ضوء التطور المتسارع في كفالة حقوق الانسان وحرياته الأساسية. وهذا التوجه يتمثل خاصة في: إلغاء عقوبة الاعدام أو عدم إتخاذها، والغاء العقوبات البدنية، والامتناع عن عقوبة الاشغال الشاقة، وإعتماد بدائل العقوبة الجنائية، وتوسيع أسس الاعفاء من المسؤولية الجنائية أو تخفيفها، وإعتماد تدابير خاصة بالاحداث، والحد من العقاب. ه- يرتبط التوجه المتعلق بتوسيع دائرة التجريمفي السياسة الجنائية المعاصرة بظهور أنواع جديدة من الجرائم إرتباطاً بالتطورات العاصفة التي يشهدها البمتمع البشري، في مختلف المجالات الإجتماعية والاقتصادية والسياسية،

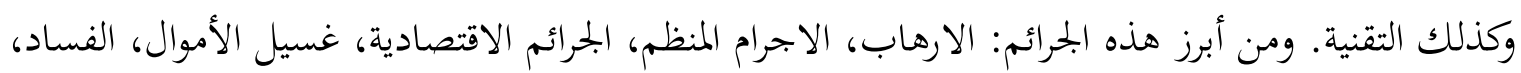
جرائم البيئة، الاستغلال الجنسي للأطفال، الجرائم المرتبطة بالأمن النووي والاشعاعي، الجرائم الطبية. 

إصلاح قانون العقوبات ومستلزمات إقامة الحكم الرشيد المتسب التوجه المرتبط بتدويل القانون الجنائي أهمية كبيزة في السياسة الجحنائية المعاصرة، وهو يرتبط بظهور القانون الدولي الجنائي، والتعاون الدولي في مواجهة الجرائم الدولية، وكذلك الجرائم ذات الطبيعة الدولية، فضلاً عن ظهور صور جديدة من الاجرام العابر للحدود، أو المرتبطة بإنتهاكات حقوق الانسان وحرياته الاساسية، ما إستوجب تدخل البحتمع الدولي لمكافحتها. وعلى رأس هذه الجرائم : جرائم الابادة الجماعية والجرائم ضد الانسانية وجرائم الحرب والاتحار بالبشر والفساد والتعذيب، وغيرها. ثانياً: التوصيات:

1 - من أجل الاضطلاع بعملية إصلاح متكامل لقانون العقوبات العراقي رقم (111) لعام 1979 ا نقترح أن تكلف بها لجنة من الحقوقيين المتخصصين بالقانون الجنائي، ممن لديهم بحوث متعددة في دراسة هذا القانون، على أن تضم هذه اللجنة أيضاً عدداً من العاملين في سلك القضاء، من ذوي الخبرة الكافية في تطبيقاته. ץ- إن عملية إصلاح قانون العقوبات العراقي يتوجب أن تكون شاملة من حيث إستظهار ثغراته، سواءً أتعلق الأمر بصياغته التشريعية الحالية، أم عدم دقة أحكامه، أم نواقصه. ب- من الأهمية بمكان في مسار عملية إصلاح هذا القانون الاسترشاد بتجربة السياسة التشريعية للقوانين العقابية في الدول الأخرى، ولاسيما تلك الدول التي قطعت شوطاً كبيراً في هذا المضمار. ع - إن إصلاح قانون العقوبات العراقي يتوجب أن يقوم على دراسة السياسة الجنائية المعاصرة، والعمل على تحسيد مظاهرها في إحكامها، تلك التي كرس هذا البحث لتوضيح أبرزها. ه- إن عملية إصلاح قانون العقوبات هي عملية مستمرة، فالسياسة الجنائية، بمحاورها الرئيسة (التجريم والعقاب والردع) في تطور متواصل، ما يستدعي أن يكون المشرع العراقي على دراية مباشرة به، ومتابعة لكل جديد طارئ، من أجل إجراء التعديالت المتطلبة على أحكام قانون العقوبات في وقته. 
قائمة المصادر

أولاً: باللغة العربية: - n

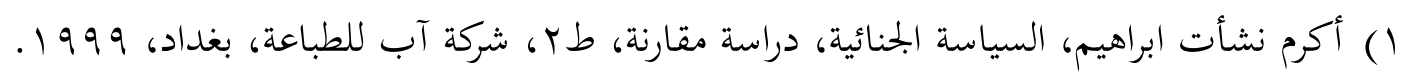

Y r توفيق فرج، المدخل للعلوم القانونية، الدار الجامعية، بيروت، ب9919.

ץ) جاسم العبودي، التجريم والعقاب في إطار الواقع الاجتماعي، دار الحكمة للطباعة والنشر، أربيل، .99 19.

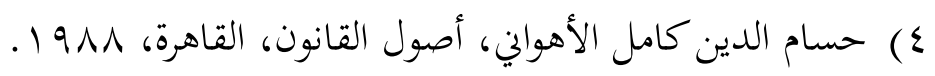

0) حسين عبدعلي عيسى، الاتحاهات الرئيسة لتطوير التشريع العقابي العراقي، القانون والسياسة، كلية القانون

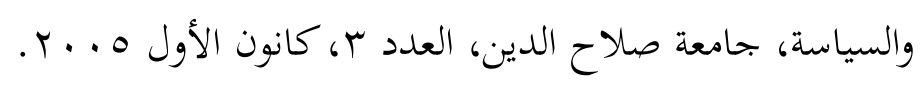

7) حسين عبدعلي عيسى، المبادئ الدستورية للسياسة الجنائية، بحلة جامعة السليمانية (كوفارى زانكوى

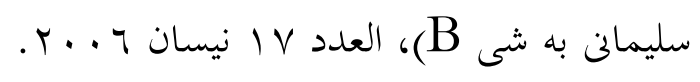

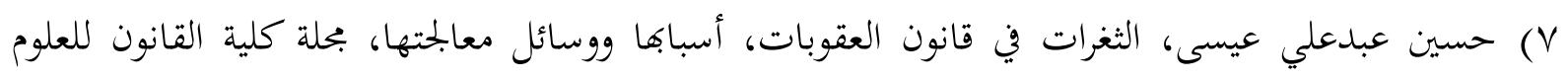

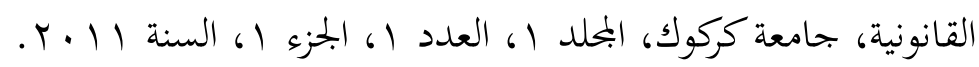

^) حسين عبدعلي عيسى، أهمية الصياغة التشريعية لقانون العقوبات في تكييف الوقائع الاجرامية، بحلة جامعة

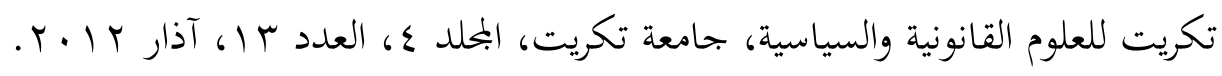

9) دينيس لويد، فكرة القانون، ترجمة سليم الصويص، المجلس الوطني للثقافة والفنون والآداب، الكويت. • 1) روسكو باوند، مدخل الى فلسفة القانون، ترجمة صلاح دباغ، المؤسسة الوطنية للطباعة والنشر، بيروت، $.197 \mathrm{~V}$

11) ساكار على محمود، الإتحار غير المشروع بالأعضاء البشرية، دراسة تحليلة مقارنة، رسالة ماجستير، كلية

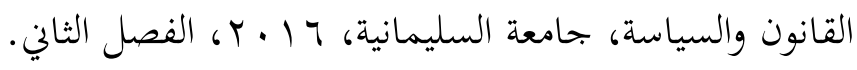

Y I ) سمير تناغو، النظرية العامة للقانون، منشأة المعرف، القاهرة، 1919 ب ا ) السيد يس، السياسة الجنائية المعاصرة، دار الفكر العربي، القاهرة، بلو 1. ع (1) عبدالباقي البكري، زهير البشير، المدخل لدراسة القانون، بيت الحكمة للنشر والترجمة والتوزيع، بغداد، ب.ت.تأريخ النشر. 


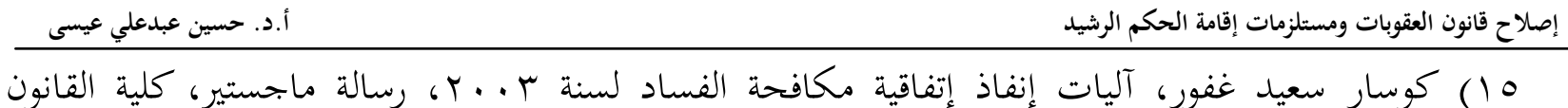

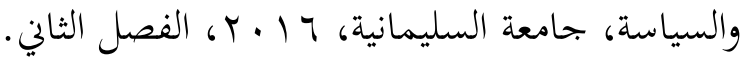

7 ( ) نبيل ابراهيم سعد، د. محمد حسن قاسم، المدخل الى القانون، القاعدة القانونية - نظرية الحق، منشورات

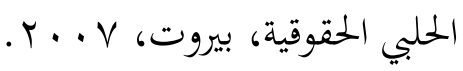

V هنري باتيفول، فلسفة القانون، ترجمة د. سموحي فوق العادة، منشورات عويدات، بيروت- باريس، ع \ه ا. ثانياً: باللغة الروسية: ( ) أشجوف إكن.، سيلياكوف ن.أ. التشريع الجنائي لدول الإتحاد الأوربي، موسكو، هـ . . ب. r) آنانيان ل.ل. بعض مشاكل السياسة الجنائية في بلدان أوربا الشمالية، موسكو، ب99 19 ـ.

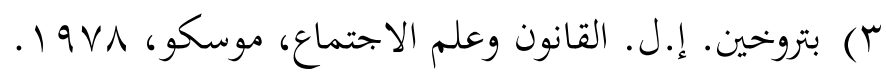
ع) براتوس.س. بشجوف.ف. الأسس النظرية لتطوير التشريع السوفيتي، بحلة الشرعية الاشتراكية، 97V) العدد (r). (r) 0) التأريخ العالمي للدولة والقانون، معجم موسوعي، موسكو، ا ... . . 7) شالينسكي أ.إ. القانون الجنائي الألماني المعاصر، دار الطريق، موسكو، ج . . †. V) شجدانوف يو.ن. ليخافسكايا.إ.س. القانون الجنائي الأوربي، آفاق التطوير، دار العلاقات الدولية، موسكو، $. T . .1$

^) غالبرين إ.م. السياسة الجنائية والتشريع الجنائي/ في كتاب:التوجهات الأساسية لمكافحة الاجرام، موسكو، $.19 \vee 0$

9) قانون العقوبات، بتربة الأنموذج النظري، تحت إشراف ف.ن.كودريافتسوف س.غ. غالينا، دار العلم، موسكو، 1918V

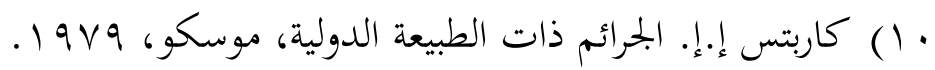

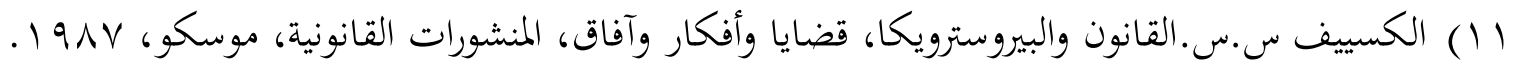

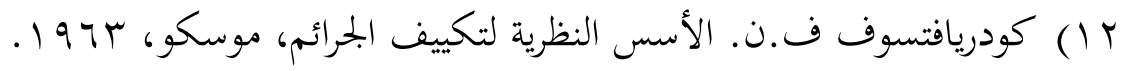
ب (1) كودريافتسوف ف.ن. القانون، الإنتهاك، المسؤولية، موسكو، دار العلم، 7191 ا. 
ـ ( ) كودريافتسوف ف.ن.شروط فاعلية القواعد القانونية/ في كتاب: فاعلية القواعد القانوينة، المنشورات

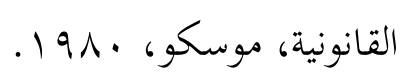

10) كورس القانون الجنائي، البحلد الخامس، القسم الخاص ، تحت إشراف غ.ن. بورزنكوف، ف.س.كمساروف، موسكو، r. r. r. r.

11) كوزاجكين إ.د. القانون الجنائي للولايات المتحدة الأمريكية: بنحاحات الاصلاح ومشاكله، موسكو، .$Y \cdot V$

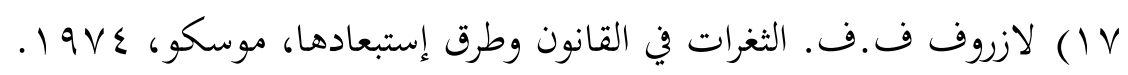

1 1) لوكاشوفا.إ.آ. المعضلات الاجتماعية - الاخلاقية للشرعية، بحلة الدولة والقانون، ب 91 ا، العدد (ع). 9 1) المحكمة الأوربية لحقوق الإنسان، قرارات مختارة،، البحلد الأول، نورما، موسكو، ... . . .

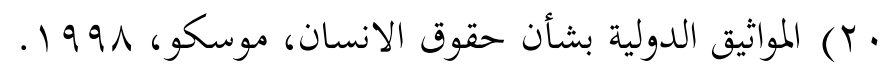

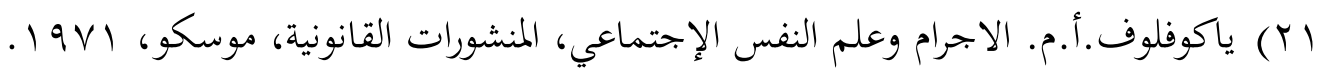
ثالثاً: المصادر الألكترونية: ( ) وثائق منظمة الأمم المتحدة، متاحة على الموقع الألكتروين:

http://www.un.org/ar/documents/index.html

$$
\text { r القوانين العقابية الأجنبية (غير العربية) على الموقع الالكتروني: }
$$

http:/www.twirpx.com/files/law/criminal/foreign/codes/

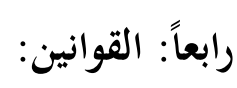

$$
\begin{aligned}
& \text { 1) قانون العقوبات العراقي رقم (11) لسنة } 11979 \text { لـ } 119
\end{aligned}
$$

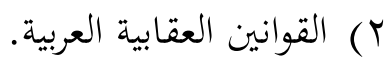

$$
\begin{aligned}
& \text { r) القوانين العقابية الأجنبية. }
\end{aligned}
$$

